\title{
Role of retinoid signaling in the regulation of spermatogenesis
}

\author{
S.S.W. Chung a and D.J. Wolgemuth ${ }^{\mathrm{a}, \mathrm{b}, \mathrm{c}, \mathrm{d}, \mathrm{e}}$ \\ Departments of ${ }^{\mathrm{a}}$ Genetics and Development and ${ }^{\mathrm{b}}$ Obstetrics and Gynecology; ${ }^{\mathrm{c}}$ The Center for Reproductive Sciences; \\ $\mathrm{d}$ The Institute of Human Nutrition, and ${ }^{\mathrm{e}}$ The Herbert Irving Comprehensive Cancer Center, Columbia University College of \\ Physicians and Surgeons, New York, NY (USA)
}

\begin{abstract}
While the need for vitamin A for the normal progression of male germ cell differentiation has been known for many years, the molecular mechanisms underlying this requirement are poorly understood. This review will explore the aspects of the effects on spermatogenesis of dietary deprivation of vitamin A, in particular as to how they compare to the male sterility that results from the genetic ablation of function of the
\end{abstract}

retinoid receptor RAR $\alpha$. The effects of other genes involved with retinoid synthesis, transport, and degradation are also considered. The possible cellular mechanisms that may be affected by the lack of retinoid signaling are discussed, in particular, cell cycle regulation and cell-cell interaction, both of which are critical for normal spermatogenesis.

Copyright $(2004$ S. Karger AG, Basel

\section{Overview of vitamin A and spermatogenesis}

\section{Historical perspective and goals of this review}

The need for dietary retinol or vitamin A for normal spermatogenesis has been recognized for decades (Wolbach and Howe, 1925; Howell et al., 1963; reviewed in Eskild and Hansson, 1994; Packer and Wolgemuth, 1999). While considerable insight has been obtained as to the molecular basis for this requirement, in particular from targeted mutagenesis of genes important at various levels of retinoid metabolism, transport, and receptor activity, the mechanisms underlying specific requirement for retinol and its active metabolite all trans-retinoic acid (ATRA) in regulating spermatogenesis remain to be elucidated. Mutagenesis of the mouse RAR $\alpha$ receptor gene resulted in disruptions in spermatogenesis that were noted to be similar

This work was supported by P01 DK54057, Project 5, to D.J.W. and fellowships from the Croucher Foundation, Hong Kong to S.S.W.C.

Received 15 November 2003; manuscript accepted 22 December 2003.

Request reprints from: Dr. Debra J. Wolgemuth

Department of Genetics \& Development

Columbia University College of Physicians \& Surgeons

$630 \mathrm{~W} .168^{\text {th }}$ street, New York NY10032 (USA)

telephone: +1-212-305-7900; fax: +1-212-305-6084

e-mail:djw3@columbia.edu to those observed in the vitamin A-deficient (VAD) rat testis (Lufkin et al., 1993), although detailed comparisons have not yet been reported in the mouse models. Further, it is still not clear whether the abnormalities observed in testes deprived of ATRA signaling from conception (RAR $\alpha$-deficient mice) would be phenocopied by the induction of VAD in the animal after spermatogenesis has been established. Conversely, it is equally unclear as to whether all of the effects of VAD would be manifested in animals deficient for a single retinoic acid receptor, as in the RAR $\alpha$-deficient mice. While many potential targets of RAR $\alpha$ have been identified from studies screening for ATRA-induced up-regulation or down-regulation of genes or for genes containing retinoic acid response elements (RAREs), those which might be important for spermatogenesis, a key physiological target of vitamin A function, remain unknown.

This review will not attempt to provide a comprehensive overview of vitamin A function during development and differentiation or of the mechanisms of retinoic acid signaling. Rather, it will explore what has been learned about these functions that are important specifically during spermatogenesis and that depend upon signaling via RAR $\alpha$ in particular. It will also consider the basic cellular processes within testicular cells that may be regulated by retinol and ATRA, with a focus on cells within the seminiferous tubules. For discussion of retinoid signaling in other compartments, the reader is referred to Livera et al. (2000, 2002) and Lopez-Fernandez and del Mazo (1997).

\begin{tabular}{lll}
\hline KARGER & $\begin{array}{l}\text { Fax }+41613061234 \\
\begin{array}{l}\text { E-mail karger@karger.ch } \\
\text { www. karger.com }\end{array}\end{array}$ & ○ 2004 S. Karger AG, Basel \\
$0301-0171 / 04 / 1054-0189 \$ 21.00 / 0$
\end{tabular}

Accessible online at: www. karger.com/cgr 


\section{Brief overview of mammalian spermatogenesis}

Spermatogenesis is a highly regulated process of differentiation and complex morphologic alterations that leads to the formation of sperm in the seminiferous epithelium. In adult male mammals, it can be subdivided into three main phases: spermatogonial proliferation, meiosis of spermatocytes, and spermiogenesis of haploid spermatids. In rodent testes, differentiating spermatogenic cells form defined associations called stages of the cycle of the seminiferous epithelium (stages I to XII in mouse and stages I to XIV in rat) that can be identified by morphologic criteria (Oakberg, 1956; Russell et al., 1990). The length of the cell cycle and pattern of cell associations, as well as the time necessary to produce spermatozoa, vary greatly among species (Russell et al., 1990). However, genetic control of the timing appears to be fixed, intrinsic to the germ cell, and cellautonomous. This was clearly evidenced by the rat-specific timing of spermatogenesis observed in rat germ cells transplanted into mouse testes (Franca et al., 1998).

During spermatogonial proliferation, undifferentiated type A spermatogonia, subdivided into $A_{\text {isolated }}\left(A_{\text {iso }}\right), A_{\text {paired }}\left(A_{\text {pr }}\right)$, and $\mathrm{A}_{\text {aligned }}\left(\mathrm{A}_{\mathrm{al}}\right)$ spermatogonia according to their topographical arrangement on the basement membrane and associated cells, divide mitotically. In response to unknown signals, they then form $A_{1}$ spermatogonia, which are the first generation of differentiating spermatogonia (de Rooij, 1998, 2001; Russell et al., 1990). In mouse, these differentiated diploid $A_{1}$ spermatogonia synchronously go through a series of six divisions, forming sequentially $A_{2}, A_{3}, A_{4}$, intermediate, and type $B$ spermatogonia. After the last mitosis of type B spermatogonia, preleptotene spermatocytes are formed. They then initiate meiosis and give rise to leptotene and zygotene spermatocytes. These cells differentiate into pachytene and diplotene spermatocytes, followed by two meiotic divisions and formation of haploid step 1 spermatids. Thereafter, spermatids undergo spermiogenesis, during which the nucleus of the germ cell is remodeled and compacted into the form that is found in mature spermatozoa. Haploid spermatids are morphologically classified into 16 steps in the mouse and 19 steps in the rat (Russell et al., 1990). Spermatogenesis culminates in spermiation, when spermatozoa are released from Sertoli cells into the lumen of the tubule.

\section{What happens as a result of vitamin A deficiency in testis?}

Early studies of the specific functions of vitamin A in reproduction were complicated by the overall poor health of VAD animals. The discovery that ATRA could alleviate most of the symptoms of VAD except defects in vision and male fertility has allowed the exploration of the effects on spermatogenesis upon deprivation of vitamin A from the diet (Dowling and Wald, 1960; Thompson et al., 1964). The changes that occur in the VAD rat testis have been studied extensively (reviewed in detail by de Rooij et al., 1989; Griswold et al., 1989; Kim and Wang, 1993; Eskild and Hansson, 1994). For example, examination of the sequence and kinetics of spermatogenic cell disappearance following the onset of VAD revealed that all stages of spermatids in VAD rat testes decreased abruptly from day 2 following the initial loss of body weight (designated as the growth retardation phase of VAD). Spermatids disappeared from the tubules by day 10 , while primary spermatocytes decreased markedly during days 5-12. Degeneration of spermatids has also been observed (Mitranond et al., 1979; Sobhon et al., 1979), along with a disruption of Sertoli cell-spermatid association (Huang et al., 1988) and a delay in spermiation (Huang and Marshall, 1983; Morales and Griswold, 1991). The rapid disappearance of spermatids and spermatocytes from the tubules at the onset of growth retardation phase of VAD suggests that the mechanisms responsible for spermiogenesis, completion of spermiation, and differentiation of spermatocytes are extremely sensitive to change in the status in vitamin A. During the same time period following the onset of growth retardation, the decrease in the number of spermatogonia was reported to be gradual and comparatively low (Mitranond et al., 1979; Sobhon et al., 1979). However, a reduction of spermatogonial population (A and B type) was obviously noted by day $16-20$, where only approximately $25 \%$ of the spermatogonia remained. This suggested the requirement of vitamin $\mathrm{A}$ in the maintenance of the spermatogonial population as well.

It is important to consider whether the effects of VAD occur directly on the germ cells or are a result of disrupted Sertoli cell-germ cell interactions. It is clear that any failure in proper functioning of the specialized junctions found between Sertoli cells and germ cells or between Sertoli cells would alter the microenvironment in the adluminal compartment of the tubules, wherein lie the spermatocytes and spermatids. Alteration of the microenvironment in the adluminal compartment due to improper Sertoli cell function could therefore be responsible for the degeneration of these spermatogenic cells. Ismail and Morales (1992) studied the effect of VAD on tight junction formation and found that it remained intact even during the severe regression three to four weeks after the onset of growth retardation. Although Huang and colleagues (1988) reported that deprivation of vitamin A has resulted in a disruption of interSertoli cell tight junctions in rats on a VAD diet as early as at around 10 days after growth retardation phase, abnormalities in germ cells were observed before this period. This suggests that the degeneration of germ cells occurring in VAD rats was not due to a breakdown of the inter-Sertoli cell tight junctions, but instead, was an immediate consequence of the absence of vitamin A. Recent studies support the effect of VAD on Sertoli cell tight junctions, noting that lanthanum nitrate penetrated deeply into the seminiferous cords in VAD rat testis (3-9 weeks after the onset of growth retardation) (Morales and Cavicchia, 2002). The Sertoli cell barrier could be restored by vitamin A replenishment following prolonged VAD (7-9 weeks after the onset of growth retardation). Interestingly, in testes of animals in which vitamin A was restored and spermatogenesis was resumed, intercellular tracer continued to freely penetrate the inter-Sertoli spaces surrounding not only preleptotene spermatocytes, but also the zygotene and pachytene spermatocytes (Morales and Cavicchia, 2002). Zygotene and pachytene spermatocytes were thus forming without an intact Sertoli cell tight junctional barrier, although some of these cells exhibited apoptosis.

Subsequent, more detailed analyses revealed defects at specific stages of spermatogonial proliferation and differentiation and at the entry into meiotic prophase, i.e. the transition of spermatocytes from preleptotene to leptotene (de Rooij and 
Table 1. Retinoid receptors and testicular function

\begin{tabular}{|c|c|c|c|}
\hline Receptors & Phenotype of knockout males & Germ cells $^{\mathrm{a}}$ & Sertoli cells \\
\hline \multirow[t]{5}{*}{$\operatorname{RAR} \alpha$} & Sterile & $\begin{array}{l}\text { B-SG, PL, L, Z, RS, ES (Akmal } \\
\text { et al., 1997) }\end{array}$ & $\begin{array}{l}\text { SC throughout postnatal } \\
\text { development }\end{array}$ \\
\hline & \multirow[t]{4}{*}{ Morphology similar to VAD testis (Lufkin et al., 1993) } & $\begin{array}{l}\mathrm{Nu} \text { (early and late SP and ES) } \\
\text { (Dufour and Kim, 1999) }\end{array}$ & $\begin{array}{l}\mathrm{Cy}(\mathrm{SC}) \text { in young animals and } \\
\text { partially translocated into } \mathrm{Nu} \text { in } \\
\text { adults (Dufour and Kim, 1999) }\end{array}$ \\
\hline & & $\begin{array}{l}\text { PS (Kim and Griswold, 1990) } \\
\text { RS (Eskild et al., 1991) }\end{array}$ & SC (Kim and Griswold, 1990) \\
\hline & & A-SG (de Rooij et al., 1994) & $\begin{array}{l}\text { SC (Akmal et al., 1997; Kim and } \\
\text { Akmal, 1996) }\end{array}$ \\
\hline & & $\begin{array}{l}\text { RS (Kim and Akmal, 1996) } \\
\text { A-SG, In, early SP, RS (Akmal et } \\
\text { al., 1997) }\end{array}$ & \\
\hline \multirow[t]{4}{*}{ RAR $\beta$} & \multirow[t]{4}{*}{ Normal spermatogenesis (Luo et al., 1995) } & $\begin{array}{l}\text { Cy (SG, early meiotic and PS) } \\
\text { throughout development (days } \\
5-52) \text { (Dufour and Kim, 1999) }\end{array}$ & $\begin{array}{l}\text { SC throughout postnatal } \\
\text { development }\end{array}$ \\
\hline & & & $\begin{array}{l}\text { Cy }(\mathrm{SC}) \text { in young animals \& } \\
\text { partially translocated into } \mathrm{Nu} \text { in } \\
\text { adults (Dufour and Kim, 1999) }\end{array}$ \\
\hline & & $(-)$ (Kim and Griswold, 1990) & SC (Kim and Griswold, 1990) \\
\hline & & --- & Cy (SC) (de Rooij et al., 1994) \\
\hline \multirow[t]{4}{*}{$\mathrm{RAR} \gamma$} & Normal spermatogenesis & $(-)($ Dufour and Kim, 1999) & $\begin{array}{l}\text { First in SC in rats at } 30-35 \text { days } \\
\text { of age }\end{array}$ \\
\hline & \multirow[t]{3}{*}{$\begin{array}{l}\text { Sterile due to abnormal seminal vesicles and prostate } \\
\text { glands (Lohnes et al., 1993) }\end{array}$} & & $\begin{array}{l}\text { Mainly Nu (SC) (Dufour and } \\
\text { Kim, 1999) }\end{array}$ \\
\hline & & PS, RS, ES (Huang et al., 1994) & SC (Huang et al., 1994) \\
\hline & & A-SG (de Rooij et al., 1994) & (-) (de Rooij et al., 1994) \\
\hline \multirow[t]{3}{*}{$\mathrm{RXR} \alpha$} & \multirow[t]{3}{*}{$\begin{array}{l}\text { Died in utero between embryonic days } 13.5 \& 16.4 \\
\text { (Kastner et al., 1994) }\end{array}$} & $\begin{array}{l}\text { Cy (SG, early and late SP, RS) } \\
\text { throughout development (days 5- } \\
\text { 52) (Dufour and Kim, 1999) }\end{array}$ & $\begin{array}{l}\text { SC throughout postnatal } \\
\text { development }\end{array}$ \\
\hline & & $\begin{array}{l}\text { A-SG, SP, ST (Gaemers et al., } \\
\text { 1998) }\end{array}$ & $\begin{array}{l}\text { Mainly in Cy (SC) in the young } \\
\text { animals \& partially translocate } \\
\text { into } \mathrm{Nu} \text { in adults (Dufour and } \\
\text { Kim, 1999) }\end{array}$ \\
\hline & & RS (Kastner et al., 1996) & --- \\
\hline \multirow[t]{3}{*}{$\operatorname{RXR} \beta$} & \multirow[t]{3}{*}{$\begin{array}{l}\text { Sterile because of abnormal spermiogenesis (Kastner et } \\
\text { al., 1996) }\end{array}$} & (-) (Dufour and Kim, 1999) & $\begin{array}{l}\text { First in SC in rats at } 30-35 \text { days } \\
\text { of age }\end{array}$ \\
\hline & & & $\begin{array}{l}\text { Mainly Nu (SC) (Dufour and } \\
\text { Kim, 1999; Kastner et al., 1996) }\end{array}$ \\
\hline & & (-) (Kastner et al., 1996) & SC (Kastner et al., 1996) \\
\hline $\mathrm{RXR} \gamma$ & Normal spermatogenesis (Krezel et al., 1996) & $\begin{array}{l}\mathrm{Nu} \text { (SG, early and late SP and } \\
\text { RS, ES) (Dufour and Kim, 1999) } \\
\text { A-SG, PS (Gaemers et al., 1998) }\end{array}$ & $\begin{array}{l}\text { SC throughout postnatal } \\
\text { development } \\
\text { Mainly Nu (SC) (Dufour and } \\
\text { Kim, 1999) }\end{array}$ \\
\hline
\end{tabular}

a Cy, cytoplasm; Nu, nucleus; A-SG, A-type spermatogonia; B-SG, B-type spermatogonia; SP, spermatocytes; PL, preleptotene spermatocytes; L, leptotene spermatocytes; Z, zygotene spermatocytes; PS, pachytene spermatocytes; RS, round spermatids; ES, elongated spermatids; (-) no expression; --- unknown expression; white background, protein expression by immunohistochemical analysis; light gray background, mRNA expression by Northern blot analysis; dark gray background, mRNA expression by in situ hybridization

Ismail et al., 1990; van Pelt and de Rooij, 1990b; de Rooij et al., 1994; van Dissel-Emiliani, 1997; Packer and Wolgemuth, 1999). At the onset of the growth retardation phase of VAD in rats, the production of $\mathrm{A}_{2}$ spermatogonia was arrested, and there was also a temporary arrest of preleptotene spermatocytes (Griswold et al., 1989; de Rooij et al., 1989; Ismail et al., 1990; Van Pelt and de Rooij, 1990a; de Rooij et al., 1994). Administration of either vitamin A (Griswold et al., 1989; de Rooij et al., 1989; Ismail et al., 1990; Van Pelt and de Rooij, 1990a) or intraperitoneal injection of ATRA (van Pelt and de Rooij, 1991) caused a massive and synchronous production of $A_{1}$ spermatogonia and subsequent spermatogenic stages. The formation of $A_{1}$ spermatogonia from $A_{a l}$ can be seen in response to vitamin A or ATRA even after long periods of VAD (de Rooij, 1998, 2001). Further, RARa (Rara) mRNA was readily detected by in situ hybridization in Sertoli cells and A- spermatogonia $6 \mathrm{~h}$ after injection of ATRA in VAD mice (de Rooij et al., 1994). The differentiation of $A_{a l}$ into $A_{1}$ spermatogonia appears to be a rather vulnerable stage because it can be blocked in a number of different situations, including VAD, elevated testosterone levels, and high testicular temperature (reviewed in de Rooij and Grootegoed, 1998; de Rooij, 2001). This stage also appears to be affected in specific genetic lesions, including the $S l 17 \mathrm{H} / \mathrm{Sl17H}, \mathrm{W} / \mathrm{W}^{v}$, jsd/jsd, and $\mathrm{Daz} \mathrm{l}^{-/-}$strains of mice (Brannan et al., 1992; Matsumiya et al., 1999; SchransStassen et al., 2001; Tohda et al., 2001; Ohta et al., 2003). It is not yet known whether the action of ATRA in inducing differentiation of $A_{a l}$ into $A_{1}$ is direct, or indirect via Sertoli cells, since both spermatogonia and Sertoli cells possess nuclear receptors for retinoids (Akmal et al., 1997; Gaemers et al., 1998; Cupp et al., 1999) (Table 1). 


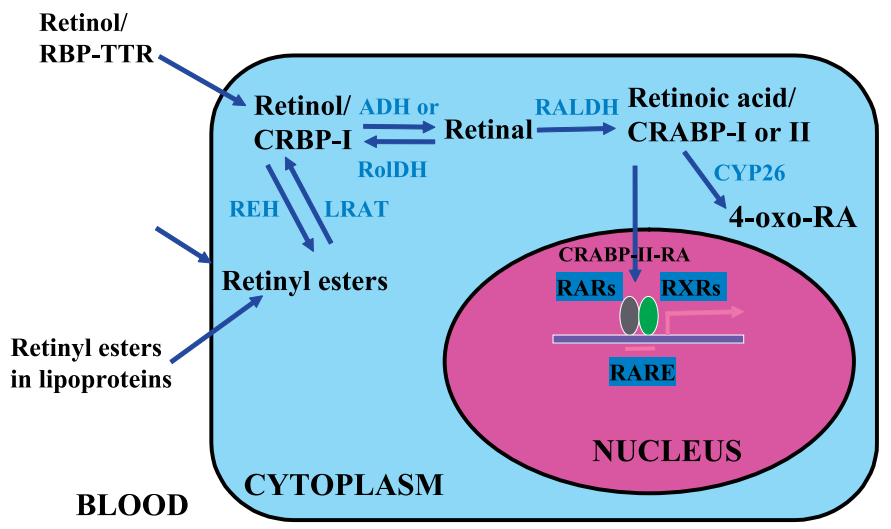

Fig. 1. Vitamin A delivery and its metabolic activation to retinoic acid. RBP, retinol-binding protein; TTR, transthyretin; CRBP-I, cellular retinolbinding protein, type I; CRABP-I, cellular retinoic acid-binding protein, type I; CRABP-II, cellular retinoic acid-binding protein, type II; ADH, mediumchain alcohol dehydrogenases; RolDH, short-chain alcohol dehydrogenase or short-chain dehydrogenase/reductase; RALDH, retinal dehydrogenase; LRAT, lecithin:retinol acyltransferase; REH, retinyl ester hydrolase. Adapted from Gottesman et al. (2001).
Collectively, at least four major defects in spermatogenesis have been identified in the adult VAD rat testis. They include failure of the production of $\mathrm{A}_{2}$ spermatogonia from $\mathrm{A}_{1}$ spermatogonia at the onset of VAD, a delay in the onset of and an abnormality in the progression of meiotic prophase, spermatid degeneration and a breakdown of inter-Sertoli cell tight junctions.

\section{How does vitamin A exert its function in the testis?}

What happens to vitamin $A$ after ingestion?

In omnivores (including humans), all vitamin A in the body must be acquired from the diet as either preformed vitamin A (primarily retinyl esters and retinol from animal sources) or provitamin A carotenoids (such as $\beta$-carotene from plants), which are subsequently converted in the body to retinal and ATRA (reviewed in Vogel et al., 1999; Gottesman et al., 2001; $\mathrm{Li}$ and Tso, 2003) (also Fig. 1). In brief, within the small intestine, dietary retinyl esters (REs) are hydrolyzed to retinol by

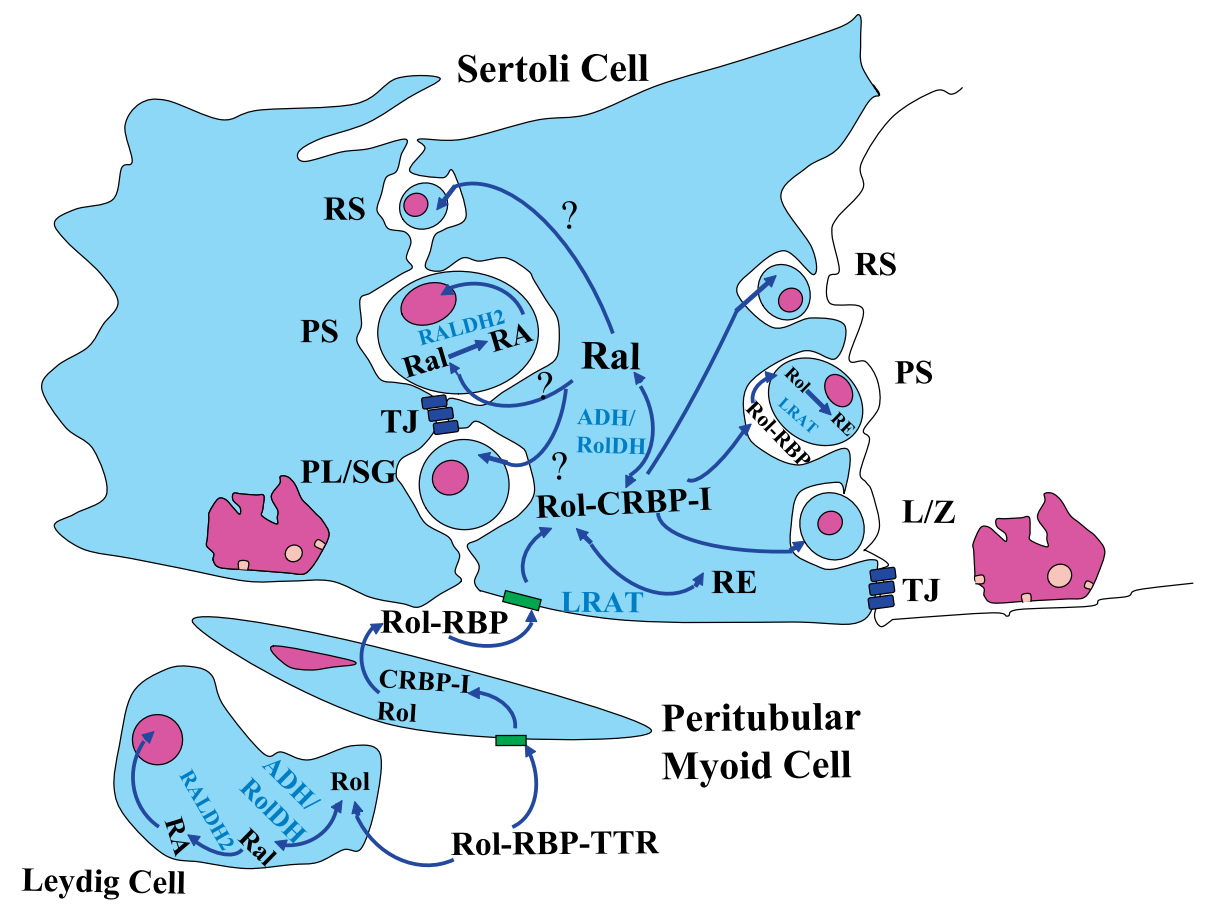

Fig. 2. Proposed retinoid metabolism, transport, and action in the seminiferous tubules of testis. Circulating retinol (Rol) is bound to RBP and complexed with TTR. It is then internalized in the peritubular myoid cells and then passes to Sertoli cells and spermatogenic cells outside the blood-testis barrier. CRBP-I is present in Sertoli cells and may facilitate retinol update from circulating retinol-RBP complexes. Rol-CRBP in Sertoli cells then oxidizes to retinal by ADH in Sertoli cells or certain spermatogenic cells (see section V). By unknown processes, Ral is transferred to spermatogenic cells. Then, RALDH1 or RALDH2 in various spermatogenic cells (SG, early meiotic spermatocytes, PS, RS) oxidizes retinal to retinoic acid; however, neither RALDH1 nor RALDH2 has been found in Sertoli or peritubular myoid cells. Alternatively, the retinol will convert to retinyl esters for storage. CRABP-I is found in the cytoplasm of spermatogenic cells where it may sequester retinoic acid in the cytoplasm and prevent ligand-dependent activation of the nuclear retinoid receptor. Accordingly, inside the blood-testis barrier, no CRABP-I was found in any cells. CRABP-II, is however, found in Sertoli cells. The expression of degrading enzymes is not well described, but is basically characterized as "being expressed in the testis". Similar pathways of uptake and metabolism are believed to function in Leydig cells as in Sertoli cells. RBP, retinol-binding protein; TTR, transthyretin; CRBP-I, cellular retinol-binding protein, type I; CRABP-I, cellular retinoic acid-binding protein, type I; CRABP-II, cellular retinoic acid-binding protein, type I; ADH, medium-chain alcohol dehydrogenases; RolDH, short-chain alcohol dehydrogenase or short-chain dehydrogenase/reductase; RALDH, retinal dehydrogenase; LRAT, lecithin:retinol acyltransferase; REH, retinyl ester hydrolase. PL/SG, preleptotene spermatocytes or spermatogonia; L/Z, leptotene/ zygotene spermatocytes; PS, pachytene spermatocytes; RS, round spermatids; TJ, tight junction, Sertoli cell barrier. Adapted from Livera et al. (2002) and Kim and Akmal (1996). 
one or more of the retinyl ester hydrolases (REHs). Provitamin A carotenoids are cleaved to retinal which can be then reduced to retinol. Retinol is bound to cellular retinol-binding protein, type II (CRBP-II) and subsequently esterified to REs through the action of lecithin:retinol acyltransferase (LRAT). REs are then packaged along with other dietary lipids into chylomicrons and secreted into the lymphatic system. The chylomicron REs are internalized in the liver by hepatocytes. Within hepatocyte and hepatic stellate cells, retinol is bound to cellular retinol-binding protein, type I (CRBP-I). CRBP-I has been proposed to carry retinol to newly synthesized serum retinol-binding protein (RBP). The RBP-retinol complex is then secreted into the circulation to meet tissue vitamin A needs. Alternaltively, LRAT in the hepatocytes can esterify retinol to RE, which is the primary form for storage. Hepatic RE levels in mice are particularly high as compared to other animals, a fact that has complicated VAD studies in mice (McCarthy and Cerecedo, 1952; Smith et al., 1987).

Within cells, retinol is either esterified for storage or converted to active metabolites, such as retinals and retinoic acids (Fig. 1, reviewed in Blaner et al., 1999; Gottesman et al., 2001). Conversion of retinol to retinal is reversible, but conversion of retinal to ATRA is irreversible. Animals maintained on a VAD diet that are supplemented with ATRA are relieved of virtually all the symptoms of VAD, except that they are blind and the males are sterile (Howell et al., 1963). The requirement for dietary retinol, not ATRA, for the maintenance of spermatogenesis is likely due to the existence of the blood-testis barrier or Sertoli cell barrier. In the rat testis, it has in fact been shown that less than $1 \%$ of ATRA is derived from the plasma pool indicating that testicular ATRA must be derived from retinol that is taken up from the serum (Kurlandsky et al., 1995) (Fig. 2).

\section{Role of retinoid-specific binding proteins}

To maintain solubility, retinoids must be bound to proteins in an aqueous environment (Noy, 1999). Many retinoid-specific binding proteins have been identified, some of which are intracellular while others are extracellular. CRBP-I and CRBPII and cellular retinoic acid-binding protein, types I and II (CRABP-I and CRABP-II) are exclusively intracellular, whereas RBP, transthyretin (TTR) and interphotoreceptor retinoidbinding protein (IRBP) are extracellular. It has been postulated that CRABPs could act as "buffers" to control spatiotemporally the actual level of "free" intracellular retinoic acid available for binding to the nuclear receptors (Mangelsdorf et al., 1994). RBP is the sole specific transport protein for retinol in the circulation and was proposed to have as its physiological function the delivery of retinol to tissues. TTR is an abundant serum protein composed of four 14-kDa monomers found in 1:1 association with RBP and has been shown to prevent glomerular filtration of RBP (Monaco, 2000).

RBP bound to TTR has been shown to participate in the transport of serum retinol to Sertoli cells via the peritubular myoid cells that surround the seminiferous tubules. In vitro studies suggest that retinol is delivered to the peritubular cells in a complex with both RBP and TTR, where it is then resecreted bound to RBP synthesized by the peritubular cells themselves (Davis and Ong, 1995). RBP protein was also shown to be synthesized and secreted by rat Sertoli cells in culture (Davis and Ong, 1992). The observation of the uptake of tritiated retinol from retinol-RBP or retinol-RBP-TTR complexes by cultured Sertoli cells led to the hypothesis that serum retinol is chaperoned by RBP and TTR first to the peritubular cells, and finally to the Sertoli cells (reviewed in Eskild and Hansson, 1994; Kim and Akmal, 1996). Although it is assumed that retinol is taken up by Sertoli cells bound by RBP-TTR, the ablation of either Rbp or Ttr by gene targeting has not revealed any effects on spermatogenesis (Episkopou et al., 1993; Quadro et al., 1999) (discussed in section V).

Using autoradiography, Rajguru and colleagues (1982) demonstrated that labeled retinol is primarily localized to three cellular sites within the adult rat testis: macrophages of the interstitial tissue, lipid droplets of the Sertoli cells, and in spermatids in association with Golgi saccules. However, the bloodtestis barrier mediated by junctions in the Sertoli cells prevents the diffusion of retinol or its metabolites into the adluminal compartment which contains the spermatocytes and spermatids (Fig. 2). That is, retinol-RBP cannot be delivered directly to these cells nor can ATRA diffuse to them. Retinol complexed with RBP can only reach Sertoli cells and spermatogenic cells outside the barrier, i.e. the basal compartment (Fig. 2). Thus, the mechanism by which the labeled retinol reached spermatids remains unknown.

CRBP facilitates retinol uptake by cells from circulating retinol-RBP complexes (Fig. 2). Among this family, only CRBP-I has been demonstated in testis, with expression restricted to Sertoli and peritubular myoid cells (reviewed in Eskild and Hansson, 1994). Thus, only Sertoli cells in the testis take up retinol from retinol-RBP complexes in the blood stream (Fig. 2). The cytoplasmic expession of CRBP-I in rat Sertoli cells has been shown to be stage specific, with highest expression at stage XII-XIII, and the lowest at stage VI-VIII. Recently, two additional CRBPs have been isolated and characterized. CRBP-III is distributed mainly in kidney and liver (Folli et al., 2001), while CRBP-IV has been shown to be expressed primarily in kidney, heart and transverse colon, suggesting that different intracellular mediators of retinol metabolism function in different tissues (Folli et al., 2002).

CRABP-I was found to be particularly abundant in the male and female reproductive tracts, including the testis (Ong et al., 1994). Within cells, ATRA is known to be rapidly metabolized to a number of retinoid metabolites, some of which are inactive, in a tissue-dependent manner (Napoli and McCormick, 1981). Therefore, it is likely that retinoic acid must be generated just before its action and near the site of action, probably within the target cells. The detection of both synthesizing and degradation enzymes of retinoic acid in the testis supports this hypothesis (discussed in section V). CRABPs have been shown to act to deliver ATRA to the nucleus (Takase et al., 1986). Recent studies on the molecular mechanism of CRABP function have shown that in COS-7 and MCF-7 cells, movement of ATRA to the RAR $\alpha$ receptor involves the direct channeling of ATRA between CRABP-II (and not CRABP-I) and RAR $\alpha$ (Dong et al., 1999; Budhu and Noy, 2002). 
In the testis, CRABP-I was exclusively localized to the cytoplasm of embryonic gonocytes and in spermatogonia of the post-natal and adult testis, including intermediate and B-type spermatogonia, and was never observed in Sertoli cells (Rajan et al., 1991; Zheng et al., 1996). The presence of CRABP-I exclusively in the cytoplasm of gonocytes and spermatogonia may indicate its possible role in sequestering ATRA in the cytoplasm of these mitotically dividing germ cells that are outside the blood-testis barrier mediated by Sertoli cells, thereby preventing ligand-dependent activation of the nuclear retinoic acid receptors (Zheng et al., 1996). The lack of expression of CRABP-I in the more advanced spermatogenic cells may suggest that it is not needed in cells beyond the barrier, which successfully sequesters their exposure to ATRA.

In contrast to CRABP-I, CRABP-II expression in the embryonic testis was definitively localized to Leydig and Sertoli cells using a well-characterized CRABP-II antibody (reviewed in Ong et al., 1994; Zheng et al., 1996). CRABP-II protein was detected as early as the day 16 rat fetus by immunostaining, and relatively high levels of CRABP-II mRNA were found at postnatal day (pnd) 4, with levels steadily decreasing to undetectable levels at pnd 20 (Zheng et al., 1996). The developmental pattern of expression of CRABP-II in fetal and prepubertal Sertoli cells overlaps almost exactly with the developmental timing of Sertoli cell proliferation in the rat testis (Orth, 1982; Walker, 2003; Buzzard et al., 2003), which is maximal at day 20 of gestation and decreases until pnd 21 . These correlations in expression pattern led Zheng and colleagues (Zheng et al. 1996) to propose that CRABP-II is involved in the retinoic acid-dependent autocrine or paracrine regulation of Sertoli cell proliferation.

\section{Discovery of the receptors gave insight into the mechanisms by which the metabolites of retinol could exert their functions}

The two major active isoforms of retinoic acid - ATRA and 9-cis retinoic acid (9-cis RA) - both exert the pleiotropic biological effects of vitamin A by transcriptional regulation of target genes via a class of nuclear receptors comprised of two subfamilies: the retinoic acid receptors (RARs) and the retinoid X receptors (RXRs) (reviewed in Chambon, 1995; Chambon, 1996; Leid et al., 1992). Each class of receptors contains three major subtypes $(\alpha, \beta$, and $\gamma$ ) whose distribution and function is partly overlapping and partly unique, as illustrated by gene knockout strategies (reviewed in Kastner et al., 1995; Packer and Wolgemuth, 1999). RARs are activated by either ATRA and 9-cis RA while RXRs are exclusively activated by 9-cis RA. The RARs and RXRs bind to RAREs to achieve activation or repression of target genes as $\mathrm{RAR} / \mathrm{RXR}$ heterodimers or as RXR homodimers (reviewed in Chambon, 1996; Mangelsdorf and Evans, 1995; Piedrafita and Pfahl, 1999). The RAREs consist of two direct repeats [PuG(G/T)TCA] usually separated by a spacer of 1,2, or 5 nucleotides. Over the last quarter century, more than 532 genes have been put forward as regulatory targets of ATRA (reviewed in Balmer and Blomhoff, 2002; Gudas et al., 1994; Nagpal and Chandraratna, 1998). These genes include those encoding growth factors and their receptors, hormones, protein kinases, components of the extracellular ma- trix, enzymes involved in intermediary metabolism, protooncoproteins, and HOX proteins. In some cases, this control is direct, driven by a ligand-complexed heterodimer of retinoid receptors to a RARE; in others, it is indirect, reflecting the actions of intermediate transcription factors, non-classical associations of receptors with other proteins, or even more distant mechanisms.

In normal mouse and rat testes, the cellular localization of the six retinoid receptors has been extensively studied by Northern blot analysis, in situ hybridization and immunohistochemical analysis (Table 1; reviewed in de Rooij et al., 1989; Griswold et al., 1989; Kim and Wang, 1993; Eskild and Hansson, 1994). The expression patterns of these retinoid receptors in Sertoli cells and spermatogenic cells led to several hypotheses of their possible functions in spermatogenesis; however, only RAR $\alpha$ or RXR $\beta$, but not other RARs or RXRs, have been shown by genetic ablation approaches to have effects on spermatogenesis (Lufkin et al., 1993; Kastner et al., 1996).

In $\mathrm{Rara}^{-/}$testes at 4-5 months of age, severe degeneration of the germinal epithelium was observed, with some tubules containing few or no germ cells while adjacent tubules in the same testis sample contained almost all the characteristic cell types, from spermatogonia to fully elongated spermatids (Lufkin et al., 1993). The epididymis of mutant animals contained only a few abnormal spermatozoa and the animals were sterile (Lufkin et al., 1993). No information was provided as to when the abnormalities in spermatogenesis were first observed, complicating our understanding the primary site of action of RAR $\alpha$ in the testis. That is, it is possible that RAR $\alpha$ is required at only a few steps of differentiation, perhaps even in either only the germ cell or somatic cell lineages, but the severe degeneration that was observed resulted from the disruption of the overall spermatogenic process. In such a case, the loss of other germ cell types would not be a primary result of the loss of the protein, but rather would occur as the key cell-cell interactions between various stages of germ cells and the supporting Sertoli cells are disrupted.

RXR $\beta$-deficient males are sterile, owing to oligo-asthenoteratozoospermia (Kastner et al., 1996). Failure of spermatid release in the seminiferous epithelium and abnormal acrosomes and tails of spermatozoa in the epididymis were also noted. There was a progressive accumulation of lipids within the mutant Sertoli cells, characterized as unsaturated triglycerides. RXR $\beta$ has been shown to be expressed exclusively in Sertoli cells; hence, these cells are likely the primary site of RXR $\beta$ signaling during spermatogenesis.

Disruption of RAR $\gamma$ also resulted in male sterility but not due to abnormal spermatogenesis; rather, there were abnormalities in the seminal vesicles and prostate glands (Lohnes et al., 1993). A squamous metaplasia of the glandular epithelia of the prostate and seminal vesicles was observed, which was also noted to be a characteristic symptom of VAD (Thompson et al., 1964). $\mathrm{Rara}^{-/} \mathrm{Rarg}^{-/}$double mutant males also showed severely abnormal genital ducts (Lohnes et al., 1994). RAR $\gamma$-mediated ATRA signaling is likely to perform an essential role at some stages in the ontogeny of reproductive organs, but the specific defects have not been well characterized.
Cytogenet Genome Res 105:189-202 (2004) 


\section{Focus on RARa}

\section{What testicular cell types require retinoid signaling via} $R A R \alpha$ ?

RAR $\alpha$ transcripts and protein have been reported to be expressed in most cell types in the testis, suggesting that it could play a role in processes as diverse as Sertoli cell function, meiotic prophase, and spermiogenesis (Kim and Griswold, 1990; Eskild et al., 1991; van Pelt et al., 1992; Kim and Wang, 1993; Lufkin et al., 1993; Akmal et al., 1997; Dufour and Kim, 1999). In situ hybridization analysis of developing rat testes has shown that RAR $\alpha$ transcripts increased between pnd 5 and 10 (Akmal et al., 1997). The mRNA level peaked from pnd 10 to 15 and was found primarily towards the center of seminiferous epithelium (Akmal et al., 1997). The levels then declined in pnd 20 testis. The rat testis at pnd 9 contains only type A spermatogonia and Sertoli cells, B type spermatogonia do not develop until 11 days of age, primary spermatocytes are first apparent on pnd 15 , and round spermatids appear on pnd 25 (Wing and Christensen, 1982; Yang et al., 1990; Dym et al., 1995; Malkov et al., 1998). By immunohistochemical analysis, RAR $\alpha$ proteins were also found in a similar developmental profile (Dufour and Kim, 1999). The highest expression in Sertoli and spermatogenic cells was found in the seminiferous tubules of rats at pnd 5-15 (Akmal et al., 1997). RAR $\alpha$ protein was detected in the nuclei of type A and B spermatogonia, and was high in the nuclei of preleptotene, leptotene and zygotene spermatocytes (Akmal et al., 1997; Dufour and Kim, 1999). In Sertoli cells, RAR $\alpha$ protein was reported to be present in cytoplasm throughout development and to be partially translocated into nuclei in the adult testis (Dufour and Kim, 1999).

To what extent does dietary deprivation of vitamin $A$ phenocopy loss of RAR $\alpha$ function?

In a recent study to determine the testicular cells first exhibiting abnormalities during spermatogenic differentiation in the absence of RAR $\alpha$-mediated signaling, we observed striking changes in spermatogenic cell associations that appeared to be primary as opposed to secondary events (Chung et al., 2004). The absence of the RAR $\alpha$ receptor resulted in an increased number of degenerating pachytene spermatocytes and a temporary arrest in spermiogenic progression, at step 8-9 spermatids, in the first wave of spermatogenesis. There was also a delay in the onset of the second wave, as well as a temporary arrest and delay in the appearance of preleptotene and leptotene spermatocytes in the first, second and third waves. In vivo BrdU labeling revealed a notable decrease in germ cell proliferation in both juvenile and adult $\mathrm{Rara}^{-/}$testes and confirmed the arrest at step 8-9 spermatids observed morphologically in the first wave of spermatogenesis. The net result of these abnormalities was a profound asynchrony of spermatogenic progression in $\mathrm{Rara}^{-/-}$semininferous tubules. These findings implicated RAR $\alpha$ as being essential for synchronous development of spermatogenic cells in the testis. We speculated that RAR $\alpha$ receptor-regulated factors were required for A-spermatogonia to initiate a precise series of divisions, for preleptotene spermatocytes to traverse a normal meiotic prophase, and for step 8-9 spermatids to continue to undergo spermiogenesis, respective- ly. Interestingly, in VAD rat testes, examples of temporary arrest in development of spermatogenesis have also been demonstrated, further suggesting the tightly controlled spermatogenic cell cycle can be altered by retinoids (Huang and Hembree, 1979; de Rooij, 1983; Morales and Griswold, 1987; Ismail et al., 1990; de Rooij et al., 1994).

Another striking feature of the $\mathrm{Rara}^{-/}$testes were spermatids undergoing apoptosis, apparently engulfed by Sertoli cells situated at the basal lamina (Chung, Wang, and Wolgemuth, manuscript in preparation). Huang and Marshall (Huang and Marshall, 1983) also observed the presence of late spermatids and residual bodies at the luminal edge of epithelia at stages later than stage VIII of the spermatogenic cycle in VAD rat testis, consistent with the defective spermiation of these spermatids. In normal testis, spermatogonia and meiotic spermatocytes are the primary cells that undergo apoptosis and apoptotic haploid germ cells are rarely detected (Billig et al., 1995; Callard et al., 1995; Hikim et al., 1995; Shetty et al., 1996). The death of spermatozoa, which have little cytoplasm, may not involve the classical apoptotic machinery, since caspases do not appear to be used (Weil et al., 1998). Prolonged VAD is known to cause germ cell degeneration (Mason, 1933; Thompson et al., 1964) and the phagocytosis of degenerating germ cells by Sertoli cells is normal (Fawcett, 1975). The similar findings of defects in spermiation in both the VAD and RAR $\alpha$-deficient models suggested that mechanisms leading to completion of spermiation are extremely sensitive to change in the status in vitamin A, most likely through an RAR $\alpha$ receptor-mediated pathway. Thus, the failure of the production of $\mathrm{A}_{2}$ spermatogonia from $A_{1}$ spermatogonia at the onset of VAD, a delay in the onset of and an abnormality in the progression of meiotic prophase, and spermatid degeneration are defects in spermatogenesis shared in the VAD and RAR $\alpha$-deficient models.

\section{Potential cellular processes regulated by vitamin A signaling during spermatogenesis revealed by mutation of $R A R a$}

\section{Control of cell cycle progression by retinoids}

Cell cycle progression is regulated by the sequential activity of various cyclin-dependent kinases (Cdks) (Roberts, 1999; Sherr and Roberts, 1999; reviewed in Miller and Cross, 2001; Nurse, 2002; Wolgemuth et al., 2002). Cyclins are key components of the core cell cycle machinery. These proteins constitute regulatory subunits that bind, activate, and provide substrate specificity for their associated Cdks. Regulation of cell cycle progression in mammalian cells by external factors such as retinoids generally occurs in the G1 phase of the cycle (reviewed in Rogers, 1997; Harvat and Jetten, 1999; Sherr and Roberts, 1999). Three classes of cyclins operate during the G1 to $S$ phase of mitosis in mammalian cells: D-type cyclins (D1, D2, and D3), A-type (A2), and E-type cyclins (E1 and E2) (Sherr and Roberts, 1999). Mammalian cells rely on assorted strategies of negative regulation to enforce the order of events, to provide optimal timing of phase transitions, and to maintain genomic integrity. The simplest way to negatively regulate the cell cycle is through inhibition of an essential Cdk. The activities of G1 
Cdks can be blocked by Cdk inhibitors (CKIs). The INK4 class (inhibitors of CDK4) consists of four members (p16 $6^{\text {Ink4a }}$ p15 Ink4b,$p 18^{\text {Ink4c }}$, and p19 Ink4d) that exclusively bind to and inhibit the cyclin D-dependent catalytic subunits Cdk4 and Cdk6. The Cip/Kip family includes three members (p21 Cip1, $\mathrm{p} 27^{\mathrm{Kip} 1}$, and $\mathrm{p} 57^{\mathrm{Kip} 2}$ ) that bind to both cyclins and Cdks to preferentially inhibit cyclin E- and A-dependent Cdk2 .

The possibility that retinoid signaling could be important for initiation of and progression through the cell cycle in spermatogonia, spermatocytes, and spermatids (a specialized telophase) is intriguing. Retinoids have been shown to directly affect expression of cell cycle-regulatory genes at the G1 phase of mitosis (reviewed in Rogers, 1997; Harvat and Jetten, 1999; Pestell et al., 1999; Altucci and Gronemeyer, 2001; Boyle, 2001; de Rooij, 2001). For example, in a negative regulatory mode of cell cycle progression, vitamin D and ATRA can induce expression of $\mathrm{p} 21^{\text {Cip } 1}$, which blocks Cdk activity, resulting in G1 arrest of treated U937 cells (Liu et al., 1996). The $\mathrm{p} 21^{\mathrm{Cip} 1}$ gene is a retinoic acid-responsive target gene, with an RARE in the promoter that is required to confer ATRA induction through RAR/RXR heterodimers (Liu et al., 1996). During G1-S phase, another direct inhibitor of Cdks, p27 Kip1, is phosphorylated and subjected to ubiquitin-mediated degradation (Reed, 2002). In human lung squamous carcinoma $\mathrm{CH} 27$ cells, ATRA-mediated G1 arrest is associated with induction of p27 Kip1 (Hsu et al., 2000). Interestingly, in p27Kip1 knockout mice, aberrations in the spermatogenic process were observed (Fero et al., 1996; Kiyokawa et al., 1996; Nakayama et al., 1996; Beumer et al., 1999). First, a 50\% increase in the number of A spermatogonia at stage VIII was found. Second, abnormal (pre)leptotene spermatocytes were observed, some of which seemingly tried to enter a mitotic division instead of entering meiotic prophase. By the use of immunohistochemistry, $\mathrm{p} 27^{\mathrm{Kip} 1}$ expression was seen in gonocytes from E16.5 to pnd 2, while in adult mouse testis staining was found only in Sertoli cells. This suggests a role of $\mathrm{p} 27^{\mathrm{Kip} 1}$ and possibly vitamin A signaling in the regulation of spermatogonial proliferation, and/or apoptosis, and possibly the onset of meiotic prophase in preleptotene spermatocytes. In the adult testis, the effects would be indirect, via Sertoli cells, however.

Changes in the expression of cell cycle-regulatory genes by retinol replenishment after VAD have been reported. For example, Cdc25A, whose activity is required for entry into $\mathrm{S}$ phase, is expressed in spermatogonia, pre- and post-meiotic rat germ cells and is upregulated in response to retinol (Mizoguchi and Kim, 1997). There is increased expression of cyclin D2 with retinol replenishment of VAD testis (Beumer et al., 2000). Free E2F-1 has been shown to inhibit expression of retinoic acid-responsive promoters and to inhibit RAR $\alpha$ transactivation function in P19 embryonal carcinoma cells (Costa et al., 1996); however, its effects during spermatogenesis on retinoid signaling are not known. Studies on the possible defects on these cell cycle-regulatory gene expression in the absence of RAR $\alpha$ receptor-mediated pathway may provide insight into the regulation of the cell cycle in germ cells and hence, the regulation of synchronization of the spermatogenic cycle, which was perturbed in $\mathrm{Rara}^{-/-}$mice (Chung et al., 2004).
The down-regulation of cyclin D1 protein in bronchial epithelial cells in response to ATRA is regulated at the posttranslational level, likely through increased ubiquitin-dependent proteasome degradation (Langenfeld et al., 1997). In these studies, the proteasome inhibitors calpain inhibitor I and lactacystin prevented the decrease in cyclin D1 protein expression, suggesting that ATRA somehow induced proteolysis of cyclin D1 (Langenfeld et al., 1997). Similar ATRA-mediated post-translational mechanisms have been reported to contribute to the changes in activity of $\mathrm{Cdk} 2$ and $\mathrm{Cdk} 4$, which, in the case of $\mathrm{Cdk} 4$, involve the ubiquitin-proteasome pathway (Sueoka et al., 1999). ATRA and 9-cis RA were also shown to inhibit the expression of cyclin D1 and D3 and the kinase activities of Cdk2 and Cdk4 in human breast carcinomal cells in vitro (Zhou et al., 1997). Interestingly, targeted disruption of Cdk4, the primary catalytic partner for the D-type cyclins, which is expressed in spermatogonia and early stage spermatocytes, resulted in smaller testis with reduced numbers of spermatogonia/spermatocytes with perturbed layer formation (Kang et al., 1997; Tsutsui et al., 1999; Zhang et al., 1999).

In normal testis, the ratio between self-renewal and differentiation of spermatogonial stem cells should be about 1.0. The regulatory mechanism controlling the ratio between stem cell renewal and differentiation in the testis may involve glial cell line-derived neurotrophic factor (GDNF), as overexpression of GDNF resulted in clusters of mostly single A spermatogonia in 3-week-old testes (Meng et al., 2000). GDNF, which is produced by Sertoli cells, promotes stem cell renewal (Meng et al., 2000; de Rooij, 2001). ATRA has shown to act through RARa to induce GDNF responsiveness in rat superior cervical ganglia neurons, by upregulating the expression of ligand-specific receptor for GDNF (GFR $\alpha-1)$ at both the mRNA and protein levels (Thang et al., 2000). Whether GDNF may be a possible target in RAR $\alpha$-mediated pathway in testis is unknown, but examining its expression in mutant and VAD testis is of considerable interest.

\section{Cell-cell interactions affected by loss of RAR $\alpha$ mediated signaling}

As mentioned before, in the VAD rat testis model, spermatid degeneration is associated with a delay in spermiation (Mitranond et al., 1979; Sobhon et al., 1979; Huang and Marshall, 1983; Morales and Griswold, 1991) and a disruption of Sertoli cell tight junctions has been reported (Huang et al., 1988; Morales and Cavicchia, 2002). Our studies on the Rara mutant model revealed a delay and temporary arrest at step 8-9 spermatids and a failure of spermatids to align next to the lumen for spermiation (Chung et al., 2004). The similar findings of defects in spermiation in both VAD rat testis and $\mathrm{Rara}^{-/}$ mouse testis suggested that mechanisms involved in spermiogenesis and completion of spermiation are extremely sensitive to change in the status in vitamin A, most likely through an RAR $\alpha$ receptor-mediated pathway.

Several studies have suggested the involvement of retinoid receptor-mediated signaling for induction of both tight junction (TJ)-associated molecules and barrier function. Stra6 and Stra8, whose testicular expression is affected by retinoids, are ATRA-inducible genes identified in P19 EC cells (Bouillet et 
al., 1995, 1997). Stra6 appears to encode a novel integral membrane protein whose expression localized to blood-organ barriers in several tissues (Bouillet et al., 1997). In the testis, Stra6 is expressed in a spermatogenic cycle-dependent pattern in the basal lamina membranes of Sertoli cells, particularly in stage VI-VII tubules. In Rara $^{-/-}$testes, Stra6 is expressed in almost all the tubules, suggesting that RAR $\alpha$ is required for the selective expression of Stra6 at stage VI-VII (Bouillet et al., 1997).

Treatment of rat lung endothelial cells with $1 \mu \mathrm{M}$ ATRA for 4 days was shown to induce $7 \mathrm{H} 6$ antigen, a TJ peripheral protein. It was preferentially localized at the cell border and simultaneously enhanced the barrier function two-fold, as assessed by transepithelial electrical resistance and fluxes of albumin and dextran (Satoh et al., 1996). 7H6 antigen rapidly disappeared in parallel with a decrease in the paracellular barrier function during the course of cellular ATP depletion (Zhong et al., 1994), suggesting a close association between the phosphorylation and localization of 7H6 antigen at TJ. Recently, it was reported that ATRA induced the TJ structure and expression of several TJassociated molecules, such as ZO-1, occludin, claudin-6, and claudin-7, as well as a barrier function in F9 murine EC cells. This induction was further shown to be mediated specifically by the RXR $\alpha$-RAR $\gamma$ receptor pair (Kubota et al., 2001). A delay in the assembly of ZO-1, a peripheral component protein of TJ, into the Sertoli cell barrier has been detected in $\mathrm{Rara}^{-/}$testis (SSWC and DJW, unpublished observations). Similarly, gap junctional permeability has been shown to be blocked by retinol or ATRA in other cells (Walder and Lutzelschwab, 1984; Mehta et al., 1986; Pitts et al., 1986; Brummer et al., 1991; Weiler et al., 1999). The nature of the gap junctions has not been studied in either VAD testis or in RAR $\alpha$-deficient testis, but given the observed abnormalities in Sertoli-Sertoli or Sertoli-germ cell interactions, they are likely to be affected.

\section{Additional genetic manipulations to fine-tune retinoid action - any effects on spermatogenesis?}

\section{Synthesizing enzymes}

Vitamin A signaling depends on enzymes capable of catalyzing the two-step conversion of retinol to ATRA, with ATRA then functioning as a ligand for retinoid receptors (reviewed in Blaner et al., 1999; Duester, 2000, 2001; Duester et al., 2003). Enzymes that catalyze the oxidation of retinol include the family of cytosolic medium-chain alcohol dehydrogenases (ADHs) and short-chain dehydrogenase/reductases (SDR). ADH oxidizes free retinol, but not retinol bound to CRBP-I. Four classes of $\mathrm{ADH}$ s have been reported including $\mathrm{ADH} 1, \mathrm{ADH} 2, \mathrm{ADH} 3$, and $\mathrm{ADH} 4$. In situ hybridization and immunohistochemical analysis revealed that in the testis, ADH1 is localized in Sertoli cells and Leydig cells (Fig. 2) and ADH4 in late spermatids (Deltour et al., 1997). ADH3 is ubiquitously expressed as shown by Northern blot analysis (Zgombic-Knight et al., 1995). $\mathrm{ADH} 2$ has a very limited tissue distribution, being found only in adult liver and possibly human skin (Duester, 2000). Reviews with a particular focus on the mouse SDR family including several microsomal enzymes able to oxidize retinal to reti- naldehyde in vitro may be found in the papers by Duester (2000) and Duester et al. (2003).

Targeted disruption of the Adh1, Adh3 and Adh4 genes showed normal growth and fertility (Deltour et al., 1999a, b). However, the mice exhibited marked differences in clearance of ethanol and formaldehyde: ADH1 and AHD4 both demonstrated functions in ethanol and retinol metabolism in vivo, whereas $\mathrm{ADH} 3$ functions as a formaldehyde dehydrogenase (Deltour et al., 1999a, b). ADH1 and ADH4 double null mutant mice were viable and fertile, demonstrating no additive effects of loss of both ADH1 and ADH4 (Molotkov et al., 2002). However, studies on single or double knockout mice indicated that $\mathrm{ADH} 1$ provided considerable protection against vitamin toxicity, whereas $\mathrm{ADH} 4$ promoted survival during $\mathrm{VAD}$, thus revealing largely non-overlapping functions for enzymes in retinoid metabolism (Molotkov et al., 2002). Whether the testes of the mutant strains would exhibit enhanced sensitivity to excess vitamin A or more pronounced response to VAD remains to be determined.

Retinaldehyde dehydrogenases (RALDHs) catalyze the final step of ATRA synthesis and include RALDH1, RALDH2, RALDH3 and RALDH4 (Duester et al., 2003). In testis, pachytene spermatocytes expressed RALDH1 most intensely, while spermatogonia, early meiotic spermatocytes and round spermatids expressed much less (Zhai et al., 2001). RALDH2 was highly expressed in various spermatogenic cell types including spermatogonia, early meiotic spermatocytes and pachytene spermatocytes, as well as Leydig cells (Fig. 2). Neither RALDH1 nor RALDH2 expression was detected in Sertoli or peritubular myoid cells (Zhai et al., 2001). A null mutation of Raldh2 (Aldhla2) is embryonic lethal, eliminating most mesodermal RA synthesis (Niederreither et al., 1999), whereas loss of Raldh1 (Aldhla1) eliminates ATRA synthesis only in the embryonic dorsal retina with no obvious effect on development (Fan et al., 2003). Further, RALDH1-deficient mice show no apparent gross abnormalities or defects in survival or growth, and are relatively healthy and fertile (Fan et al., 2003). The genes encoding RALDH3 (Suzuki et al., 2000) and RALDH4 (Lin et al., 2003) have been recently cloned, but the effects of targeted mutation of both genes has not yet been reported. Given their pattern of expression - Raldh3 (Aldhla3) is expressed in the ventral region of the retina (Suzuki et al., 2000) and Raldh4 (Aldhla4) in adult mouse liver and kidney (Lin et al., 2003) and not in testis - neither gene would be predicted to be important for spermatogenesis.

\section{Serum binding proteins}

As mentioned earlier, mutant mice that lack functional RBP are viable and fertile (Quadro et al., 1999). However, they showed reduced levels of plasma retinol (12.5\% of wild type), markedly impaired retinal function with abnormal vision throughout the first several months of life, and abnormal retinol mobilization with an inability to mobilize retinol from hepatic stores. Although the hepatic levels of retinol reached significantly higher levels in $\mathrm{Rbp}^{-/-}$mice at 5 months of age, short-term exposure to a VAD diet did not result in the expected drop in hepatic levels in $\mathrm{Rbp}^{-/-}$mice (Quadro et al., 1999). This indicated that $R b p^{-/-}$mice cannot mobilize hepatic retinoid stores and may become VAD more quickly (W.S. Blan- 
er, personal communication). As such, these RBP-deficient mice represent a tool for studying the onset of abnormalities of VAD during the first wave of spermatogenesis.

Although disruption of the Ttr gene resulted in mice with depressed levels of plasma retinol and thyroid hormone, the mice were healthy and fertile, and showed no apparent developmental defects (Episkopou et al., 1993). The mutation affected neither the uptake nor storage of dietary retinol. Further, the concentration of retinol and RE in testis, kidney, spleen and eye cups of mutant mice were normal, suggesting no requirement of TTR in the delivery of retinol to these tissues. TTR could be important when animals are stressed via malnutrition such as on a VAD diet, an idea that has not yet been studied.

\section{Subcellular binding proteins}

The genes for CRBP I and CRBP II have both been disrupted and the physiological actions of these proteins determined. Mice lacking CRBP I appear physiological normal, with no embryonic lethality, impaired fertility, or shortened life span (Ghyselinck et al., 1999). However, these mice have impaired storage of retinyl esters in hepatic stellate cells, indicating that CRBP I plays an important role in the transfer of retinol to and/or esterification of retinol in these cells (Ghyselinck et al., 1999). Under VAD, CRBP I-null mice exhaust their RE stores six times faster than wild-type mice, and develop abnormalities characteristic of hypovitaminosis A. Mice lacking CRBP I and maintained on a VAD diet for 14 weeks exhibited testicular degeneration with sloughing of germ cells and the appearance of irregular vacuoles in the tubules (Ghyselinck et al., 1999). The coexistence of morphological normal tubules with tubules with reduced size or devoid of germ cells, which is similar to the phenotype of the RAR $\alpha$-deficient testes, was frequently observed. At 23 weeks, it was reported that the seminiferous tubules displayed a Sertoli cell-only morphology (Ghyselinck et al., 1999). Mice lacking CRBP II also have reduced hepatic stores of vitamin A, but grow and reproduce normally (E et al., 2002). However, under a VAD diet, there is increased neonatal mortality, indicating a role of CRBP II in ensuring adequate delivery of vitamin A to the developing fetus when dietary vitamin A is limiting. The VAD phenotype on a CRBP II-null background and effects on spermatogenesis have not been reported to date.

The genes for CRABP I and CRABP II have also been disrupted and the physiological actions of these proteins have been determined in studies using single and double knockouts. CRABP I-null mice are normal in development, fertility, and life span, demonstrating that under normal homeostasis, this protein is dispensable (Gorry et al., 1994). With the exception of a minor, partially penetrant, limb malformation, CRABP IIdeficient mice were also normal with regard to development, fertility, life span and behavior (Lampron et al., 1995). In order to explore the possibility of redundant function, CRABP I/IIdouble mutant mice were generated. These mice were essentially normal, except for an enhanced penetrance of abnormalities in limb formation (Lampron et al., 1995). CRABPs could still be important for maintaining physiological levels of intracellular retinoic acid under conditions of limited supply of vitamin $A$ and it is further not known whether the testis will be affected in knockout mice under VAD.

\section{Degrading enzymes}

ATRA is a crucial signaling molecule involved in tissue morphogenesis during embryonic development. The distribution and concentration of ATRA is precisely regulated during embryogenesis by balanced complementary activities of synthesizing (RALDH) and metabolizing (CYP26) enzymes. Three classes of CYP26 have been reported including A1, B1 and $\mathrm{B} 2$ (also designated $\mathrm{C} 1$ ). Cytochrome P450 (now designated as CYP26A1) was first identified as an ATRA-inducible gene (White et al., 1997). ATRA can cause direct and rapid induction of Cyp26al due to the presence of a highly conserved 32-bp element containing a canonical, direct repeat-5 type of RARE in the $5^{\prime}$ upstream promoter region (reviewed in Ross, 2003). Cyp26b1 transcripts were detected in the developing lung, kidney, spleen, thymus and testis, whereas Cyp26al transcripts were found in the diaphragm and outer stomach mesenchyme (Abu-Abed et al., 2002). In the fetal testis, only Cyp26b1 transcripts were detected, specifically in cells located outside of the developing testicular cords (Abu-Abed et al., 2002).

By targeted mutagenesis, CYP26A1-deficient mice die during mid-late gestation with several major morphogenetic defects, leading in extreme cases to a sirenomelia ("mermaid tail") phenotype (Abu-Abed et al., 2001; Sakai et al., 2001). Cyp26a1 $1^{-/}$mice are phenotypically rescued by lowering the embryonic levels of ATRA by heterozygous disruption of the RALDH2 gene (Aldhla2) (Niederreither et al., 2002). Some of Cyp26A1 $1^{-/-}$Aldhla2 $2^{+/}$mutants can reach adulthood without any phenotypic defect apart from their abnormal tails and both males and females were fertile (Niederreither et al., 2002). Compound heterozygotes (Cyp26A1 $1^{+/-}$Aldhla $\left.2^{+/-}\right)$were healthy and fertile. This implied that retinoid homeostasis was crucial for embryonic development and presumably, for subsequent tissue function. Further, genetic ablation of Rarg also rescued mice lacking CYP26A1 from caudal regression and embryonic lethality (Abu-Abed et al., 2003). However, Cyp26a1-/-Rarg-/double mutant males and females both failed to reproduce normally (Abu-Abed et al., 2003). Cyp26c1 has been recently cloned and characterized (Tahayato et al., 2003; Taimi et al., 2003). It was expressed in the hindbrain, inner ear, first branchial arch and tooth buds during murine development (Tahayato et al., 2003). Disruption of the Cyp26b1 or Cyp26c1 genes has not yet reported.

\section{Unanswered questions}

There is still much to be learned regarding the targets of retinoid signaling in spermatogenic cells. It is not known whether there would be differences in the spermatogenic phenotypes observed in animals in which RAR $\alpha$ is only in the germ line or only in somatic cells of the testis, as compared to the present model wherein it is mutated in all the cells in the testis since the onset of gonadal development. To address this question, it would be necessary to ablate RAR $\alpha$ function specifically in one lineage or the other. One possible approach would be to achieve cell-specific ablation using the "Cre recombinase/loxP recognition sequence" system for generating conditional mutations. 
This approach is made feasible by the availability of spermatogenic stage-specific promoters that are well characterized with regard to their specificity and activity in transgenic mice (Wolgemuth and Watrin, 1991; Wolgemuth et al., 1995). Alternatively, one could consider expressing a dominant negative form of RAR $\alpha$ in specific spermatogenic stages in transgenic mice and ask if this inhibits the progression of spermatogenesis. Conversely, one could ask if expression of RAR $\alpha$ in specific spermatogenic stages would result in cell-specific rescue of the RAR $\alpha$-deficient phenotype. We anticipate that this approach will be very powerful in highlighting specific functions and pathways in which the receptor acts, pathways that are obscured when function is blocked in a ubiquitous manner, as in total null animals.
Retinol metabolism in the seminiferous tubules plays an important role in spermatogenesis, suggesting that synthesizing and degrading enzymes and the various intracellular and extracellular binding proteins should similarly play critical roles during homeostasis in the testis. However, except for those that are embryonic lethal, male mice lacking either the metabolic enzymes or the binding proteins have no fertility problem. Whether this is due to functional redundancy among the enzymes and binding proteins remains to be determined. This effort will benefit from better characterization of their patterns of expression in both control and mutant testes and studies in which dietary retinol is limiting or in excess. Further, the determination of exact pathway of retinol delivery from the circulation to specific spermatogenic cells remains to be elucidated.

\section{References}

Abu-Abed S, Dolle P, Metzger D, Beckett B, Chambon $\mathrm{P}$, Petkovich M: The retinoic acid-metabolizing enzyme, CYP26A1, is essential for normal hindbrain patterning, vertebral identity, and development of posterior structures. Genes Dev 15:226240 (2001).

Abu-Abed S, MacLean G, Fraulob V, Chambon P, Petkovich M, Dolle P: Differential expression of the retinoic acid-metabolizing enzymes CYP26A1 and CYP26B1 during murine organogenesis. Mech Dev 110:173-177 (2002).

Abu-Abed S, Dolle P, Metzger D, Wood C, MacLean G, Chambon P, Petkovich M: Developing with lethal RA levels: genetic ablation of Rarg can restore the viability of mice lacking Cyp26al. Development 130:1449-1459 (2003).

Akmal KM, Dufour JM, Kim KH: Retinoic acid receptor alpha gene expression in the rat testis: potential role during the prophase of meiosis and in the transition from round to elongating spermatids. Biol Reprod 56: 549-556 (1997).

Altucci L, Gronemeyer H: Nuclear receptors in cell life and death. Trends Endocrinol Metab 12:460-468 (2001).

Balmer JE, Blomhoff R: Gene expression regulation by retinoic acid. J Lipid Res 43:1773-1808 (2002).

Beumer TL, Kiyokawa H, Roepers-Gajadien HL, van den Bos LA, Lock TM, Gademan IS, Rutgers DH, Koff A, de Rooij DG: Regulatory role of p27kip 1 in the mouse and human testis. Endocrinology 140:1834-1840 (1999).

Beumer TL, Roepers-Gajadien HL, Gademan IS, Ka HB, de Rooij DG: Involvement of the D-type cyclins in germ cell proliferation and differentiation in the mouse. Biol Reprod 63:1893-1898 (2000).

Billig H, Furuta I, Rivier C, Tapanainen J, Parvinen M, Hsueh AJ: Apoptosis in testis germ cells: developmental changes in gonadotropin dependence and localization to selective tubule stages. Endocrinology 136:5-12 (1995).

Blaner WS, Piantedosi R, Sykes A, Vogel S: Retinoic acid synthesis and metabolism, in Nau H, Blaner WS (eds): Retinoids: The Biochemical and Molecular Basis of Vitamin A and Retinoid Action, pp 117-149 (Springer-Verlag, Berlin 1999).

Bouillet P, Oulad-Abdelghani M, Vicaire S, Garnier JM, Schuhbaur B, Dolle P, Chambon P: Efficient cloning of cDNAs of retinoic acid-responsive genes in P19 embryonal carcinoma cells and characterization of a novel mouse gene, Stral (mouse LERK-2/Eplg2). Dev Biol 170:420-433 (1995).
Bouillet P, Sapin V, Chazaud C, Messaddeq N, Decimo D, Dolle P, Chambon P: Developmental expression pattern of Stra6, a retinoic acid-responsive gene encoding a new type of membrane protein. Mech Dev 63:173-186 (1997).

Boyle JO: Retinoid mechanisms and cyclins. Curr Oncol Rep 3:301-305 (2001).

Brannan CI, Bedell MA, Resnick JL, Eppig JJ, Handel MA, Williams DE, Lyman SD, Donovan PJ, Jenkins NA, Copeland NG: Developmental abnormalities in Steel17H mice result from a splicing defect in the steel factor cytoplasmic tail. Genes Dev 6:1832-1842 (1992).

Brummer F, Zempel G, Buhle P, Stein JC, Hulser DF: Retinoic acid modulates gap junctional permeability: a comparative study of dye spreading and ionic coupling in cultured cells. Exp Cell Res 196:158163 (1991).

Budhu AS, Noy N: Direct channeling of retinoic acid between cellular retinoic acid-binding protein II and retinoic acid receptor sensitizes mammary carcinoma cells to retinoic acid-induced growth arrest. Mol Cell Biol 22:2632-2641 (2002).

Buzzard JJ, Wreford NG, Morrison JR: Thyroid hormone, retinoic acid, and testosterone suppress proliferation and induce markers of differentiation in cultured rat sertoli cells. Endocrinology 144:37223731 (2003).

Callard GV, Jorgensen JC, Redding JM: Biochemical analysis of programmed cell death during premeiotic stages of spermatogenesis in vivo and in vitro. Dev Genet 16:140-147 (1995).

Chambon P: The molecular and genetic dissection of the retinoid signaling pathway. Recent Prog Horm Res 50:317-332 (1995).

Chambon P: A decade of molecular biology of retinoic acid receptors. FASEB J 10:940-954 (1996).

Chung SSW, Sung YK, Wang XY, Wolgemuth DJ: RARalpha is required for synchronization of spermatogenic cycles and its absence results in progressive breakdown of the spermatogenic process. Dev Dyn, in press (2004)

Costa SL, Pratt MA, McBurney MW: E2F inhibits transcriptional activation by the retinoic acid receptor. Cell Growth Differ 7:1479-1485 (1996).

Cupp AS, Dufour JM, Kim G, Skinner MK, Kim KH: Action of retinoids on embryonic and early postnatal testis development. Endocrinology 140:23432352 (1999).

Davis JT, Ong DE: Synthesis and secretion of retinolbinding protein by cultured rat Sertoli cells. Biol Reprod 47:528-533 (1992).
Davis JT, Ong DE: Retinol processing by the peritubular cell from rat testis. Biol Reprod 52:356-364 (1995).

de Rooij DG: Proliferation and differentiation of undifferentiated spermatogonia in the mammalian testis, in Potten CS (ed): Stem Cells: Their Identification and Characterization, pp 89-117 (Churchill Livingstone, Edinburgh 1983).

de Rooij DG: Stem cells in the testis. Int J Exp Pathol 79:67-80 (1998).

de Rooij DG: Proliferation and differentiation of spermatogonial stem cells. Reproduction 121:347-354 (2001).

de Rooij DG, Grootegoed JA: Spermatogonial stem cells. Curr Opin Cell Biol 10:694-701 (1998).

de Rooij DG, van Dissel-Emiliani FMF: Regulation of proliferation and differentiation of stem cells in the male germ line, in Potten CS (ed): Stem Cells, pp 283-313 (Academic Press, London 1997).

de Rooij DG, Van Dissel-Emiliani FM, Van Pelt AM: Regulation of spermatogonial proliferation. Ann NY Acad Sci 564:140-153 (1989).

de Rooij DG, van Pelt AMM, Van de Kant HJG, van der Saag PT, Peters AHFM, Heyting C, de Boer P: Role of retinoids in spermatogonial proliferation and differentiation and the meiotic prophase, in Bartke A (ed): Function of Somatic Cells in the Testis, p 345 (Springer-Verlag, Berlin 1994).

Deltour L, Haselbeck RJ, Ang HL, Duester G: Localization of class I and class IV alcohol dehydrogenases in mouse testis and epididymis: potential retinol dehydrogenases for endogenous retinoic acid synthesis. Biol Reprod 56:102-109 (1997).

Deltour L, Foglio MH, Duester G: Impaired retinol utilization in Adh4 alcohol dehydrogenase mutant mice. Dev Genet 25:1-10 (1999a).

Deltour L, Foglio MH, Duester G: Metabolic deficiencies in alcohol dehydrogenase Adh1, Adh3, and Adh4 null mutant mice. Overlapping roles of Adh1 and Adh4 in ethanol clearance and metabolism of retinol to retinoic acid. J Biol Chem 274:1679616801 (1999b)

Dong D, Ruuska SE, Levinthal DJ, Noy N: Distinct roles for cellular retinoic acid-binding proteins I and II in regulating signaling by retinoic acid. J Biol Chem 274:23695-23698 (1999).

Dowling JE, Wald G: The biological function of vitamin A acid. Proc Natl Acad Sci USA 46:487 (1960).

Duester G: Families of retinoid dehydrogenases regulating vitamin A function: production of visual pigment and retinoic acid. Eur J Biochem 267:43154324 (2000) 
Duester G: Genetic dissection of retinoid dehydrogenases. Chem Biol Interact 130-132:469-480 (2001).

Duester G, Mic FA, Molotkov A: Cytosolic retinoid dehydrogenases govern ubiquitous metabolism of retinol to retinaldehyde followed by tissue-specific metabolism to retinoic acid. Chem Biol Interact 143-144:201-210 (2003).

Dufour JM, Kim KH: Cellular and subcellular localization of six retinoid receptors in rat testis during postnatal development: identification of potential heterodimeric receptors. Biol Reprod 61:13001308 (1999).

Dym M, Jia MC, Dirami G, Price JM, Rabin SJ, Mocchetti I, Ravindranath N: Expression of c-kit receptor and its autophosphorylation in immature rat type A spermatogonia. Biol Reprod 52:8-19(1995).

E X, Zhang L, Lu J, Tso P, Blaner WS, Levin MS, Li E: Increased neonatal mortality in mice lacking cellular retinol-binding protein II. J Biol Chem 277:36617-36623 (2002).

Episkopou V, Maeda S, Nishiguchi S, Shimada K, Gaitanaris GA, Gottesman ME, Robertson EJ: Disruption of the transthyretin gene results in mice with depressed levels of plasma retinol and thyroid hormone. Proc Natl Acad Sci USA 90:2375-2379 (1993).

Eskild W, Hansson V: Vitamin A functions in the reproductive organs, in Blomhoff $\mathrm{R}$ (ed): Vitamin A in Health and Disease, pp 531-559 (Dekker, New York 1994).

Eskild W, Ree AH, Levy FO, Jahnsen T, Hansson V: Cellular localization of mRNAs for retinoic acid receptor-alpha, cellular retinol-binding protein, and cellular retinoic acid-binding protein in rat testis: evidence for germ cell-specific mRNAs. Biol Reprod 44:53-61 (1991).

Fan X, Molotkov A, Manabe S, Donmoyer CM, Deltour L, Foglio MH, Cuenca AE, Blaner WS, Lipton SA, Duester G: Targeted disruption of Aldh1a1 (Raldh1) provides evidence for a complex mechanism of retinoic acid synthesis in the developing retina. Mol Cell Biol 23:4637-4648 (2003).

Fawcett DW: Ultrastructure and function of the Sertoli cell, in Hamilton DW, Greep RO (eds): Handbook of Physiology Sec 7, Endocriology, Male Reproductive System, pp 21-55 (American Physiological Society, Bethesda MD 1975).

Fero ML, Rivkin M, Tasch M, Porter P, Carow CE, Firpo E, Polyak K, Tsai LH, Broudy V, Perlmutter RM, Kaushansky K, Roberts JM: A syndrome of multiorgan hyperplasia with features of gigantism, tumorigenesis, and female sterility in p27(Kip1)deficient mice. Cell 85:733-744 (1996).

Folli C, Calderone V, Ottonello S, Bolchi A, Zanotti G, Stoppini M, Berni R: Identification, retinoid binding, and $\mathrm{x}$-ray analysis of a human retinol-binding protein. Proc Natl Acad Sci USA 98:3710-3715 (2001).

Folli C, Calderone V, Ramazzina I, Zanotti G, Berni R: Ligand binding and structural analysis of a human putative cellular retinol-binding protein. J Biol Chem 277:41970-41977 (2002).

Franca LR, Ogawa T, Avarbock MR, Brinster RL, Russell LD: Germ cell genotype controls cell cycle during spermatogenesis in the rat. Biol Reprod 59 1371-1377 (1998).

Gaemers IC, van Pelt AM, van der Saag PT, Hoogerbrugge JW, Themmen AP, de Rooij DG: Differential expression pattern of retinoid $\mathrm{X}$ receptors in adult murine testicular cells implies varying roles for these receptors in spermatogenesis. Biol Reprod 58:1351-1356 (1998).

Ghyselinck NB, Bavik C, Sapin V, Mark M, Bonnier D, Hindelang C, Dierich A, Nilsson CB, Hakansson H, Sauvant P, Azais-Braesco V, Frasson M, Picaud $\mathrm{S}$, Chambon P: Cellular retinol-binding protein I is essential for vitamin A homeostasis. EMBO J 18: 4903-4914 (1999).
Gorry P, Lufkin T, Dierich A, Rochette-Egly C, Decimo D, Dolle P, Mark M, Durand B, Chambon P: The cellular retinoic acid binding protein I is dispensable. Proc Natl Acad Sci USA 91:9032-9036 (1994).

Gottesman ME, Quadro L, Blaner WS: Studies of vitamin A metabolism in mouse model systems. Bioessays 23:409-419 (2001).

Griswold MD, Bishop PD, Kim KH, Ping R, Siiteri JE, Morales C: Function of vitamin A in normal and synchronized seminiferous tubules. Ann NY Acad Sci 564:154-172 (1989).

Gudas LJ, Sporn MB, Roberts AB: Cellular biology and biochemistry of the retinoids, in Sporn MB, Roberts AB, Goodman DS (eds): The Retinoid: Biology, Chemistry, and Medicine, 2nd ed, pp 443-520 (Raven Press, New York 1994).

Harvat B, Jetten AM: Growth control by retinoids: regulation of cell cycle progression and apoptosis. In Nau H, Blaner WS (eds): Retinoids: The Biochemical and Molecular Basis of Vitamin A and Retinoid Action, pp 239-276 (Springer-Verlag, Berlin 1999).

Hikim AP, Wang C, Leung A, Swerdloff RS: Involvement of apoptosis in the induction of germ cell degeneration in adult rats after gonadotropinreleasing hormone antagonist treatment. Endocrinology 136:2770-2775 (1995).

Howell JM, Thompson JN, Pitt GAJ: Histology of the lesions produced in the reproductive tract of animals fed a diet deficient in vitamin A alcohol but containing vitamin A acid, I. The male rat. J Reprod Fertil 5:159-167 (1963).

Hsu SL, Hsu JW, Liu MC, Chen LY, Chang CD: Retinoic acid-mediated G1 arrest is associated with induction of p27(Kip1) and inhibition of cyclindependent kinase 3 in human lung squamous carcinoma CH27 cells. Exp Cell Res 258:322-331 (2000).

Huang HF, Hembree WC: Spermatogenic response to vitamin A in vitamin A deficient rats. Biol Reprod 21:891-904 (1979).

Huang HF, Marshall GR: Failure of spermatid release under various vitamin A states - an indication of delayed spermiation. Biol Reprod 28:1163-1172 (1983).

Huang HF, Yang CS, Meyenhofer M, Gould S, Boccabella AV: Disruption of sustentacular (Sertoli) cell tight junctions and regression of spermatogenesis in vitamin-A-deficient rats. Acta Anat 133:10-15 (1988).

Huang HF, Li MT, Pogach LM, Qian L: Messenger ribonucleic acid of rat testicular retinoic acid receptors: developmental pattern, cellular distribution, and testosterone effect. Biol Reprod 51:541550 (1994).

Ismail N, Morales CR: Effects of vitamin A deficiency on the inter-Sertoli cell tight junctions and on the germ cell population. Microsc Res Tech 20:43-49 (1992).

Ismail N, Morales C, Clermont Y: Role of spermatogonia in the stage-synchronization of the seminiferous epithelium in vitamin-A-deficient rats. Am J Anat 188:57-63 (1990).

Kang MJ, Kim MK, Terhune A, Park JK, Kim YH, Koh GY: Cytoplasmic localization of cyclin D3 in seminiferous tubules during testicular development. Exp Cell Res 234:27-36 (1997).

Kastner P, Grondona JM, Mark M, Gansmuller A, LeMeur M, Decimo D, Vonesch JL, Dolle P, Chambon P: Genetic analysis of RXR alpha developmental function: convergence of RXR and RAR signaling pathways in heart and eye morphogenesis. Cell 78:987-1003 (1994).

Kastner P, Mark M, Chambon P: Nonsteroid nuclear receptors: what are genetic studies telling us about their role in real life? Cell 83:859-869 (1995).
Kastner P, Mark M, Leid M, Gansmuller A, Chin W, Grondona JM, Decimo D, Krezel W, Dierich A, Chambon P: Abnormal spermatogenesis in RXR beta mutant mice. Genes Dev 10:80-92 (1996).

Kim KH, Akmal KM: Role of vitamin A in male germcell development, in Desjardins C (ed): Cellular and Molecular Regulation of Testicular Cells, pp 83-98 (Springer-Verlag, Berlin 1996).

Kim KH, Griswold MD: The regulation of retinoic acid receptor mRNA levels during spermatogenesis. Mol Endocrinol 4:1679-1688 (1990).

Kim KH, Wang ZQ: Action of vitamin A on testis: role of the Sertoli cell, in Griswold MD, Rusell LD (eds): The Sertoli Cell, pp 514-535 (Cache River Press, Clearwater 1993)

Kiyokawa H, Kineman RD, Manova-Todorova KO, Soares VC, Hoffman ES, Ono M, Khanam D, Hayday AC, Frohman LA, Koff A: Enhanced growth of mice lacking the cyclin-dependent kinase inhibitor function of p27(Kip1). Cell 85:721-732 (1996).

Krezel W, Dupe V, Mark M, Dierich A, Kastner P, Chambon P: RXR gamma null mice are apparently normal and compound RXR alpha +/-/RXR beta -/-/RXR gamma -/- mutant mice are viable. Proc Natl Acad Sci USA 93:9010-9014 (1996).

Kubota H, Chiba H, Takakuwa Y, Osanai M, Tobioka H, Kohama G, Mori M, Sawada N: Retinoid X receptor alpha and retinoic acid receptor gamma mediate expression of genes encoding tight-junction proteins and barrier function in F9 cells during visceral endodermal differentiation. Exp Cell Res 263:163-172 (2001).

Kurlandsky SB, Gamble MV, Ramakrishnan R, Blaner WS: Plasma delivery of retinoic acid to tissues in the rat. J Biol Chem 270:17850-17857 (1995).

Lampron C, Rochette-Egly C, Gorry P, Dolle P, Mark M, Lufkin T, LeMeur M, Chambon P: Mice deficient in cellular retinoic acid binding protein II (CRABPII) or in both CRABPI and CRABPII are essentially normal. Development 121:539-548 (1995).

Langenfeld J, Kiyokawa H, Sekula D, Boyle J, Dmitrovsky E: Posttranslational regulation of cyclin D1 by retinoic acid: a chemoprevention mechanism. Proc Natl Acad Sci USA 94:12070-12074 (1997).

Leid M, Kastner P, Chambon P: Multiplicity generates diversity in the retinoic acid signalling pathways. Trends Biochem Sci 17:427-433 (1992).

Li E, Tso P: Vitamin A uptake from foods. Curr Opin Lipidol 14:241-247 (2003).

Lin M, Zhang M, Abraham M, Smith SM, Napoli JL: Mouse retinal dehydrogenase 4 (RALDH4), molecular cloning, cellular expression, and activity in 9cis-retinoic acid biosynthesis in intact cells. J Biol Chem 278:9856-9861 (2003).

Liu M, Iavarone A, Freedman LP: Transcriptional activation of the human $\mathrm{p} 21$ (WAF1/CIP1) gene by retinoic acid receptor. Correlation with retinoid induction of U937 cell differentiation. J Biol Chem 271:31723-31728 (1996).

Livera G, Rouiller-Fabre V, Durand P, Habert R: Multiple effects of retinoids on the development of Sertoli, germ, and Leydig cells of fetal and neonatal rat testis in culture. Biol Reprod 62:1303-1314 (2000).

Livera G, Rouiller-Fabre V, Pairault C, Levacher C, Habert R: Regulation and perturbation of testicular functions by vitamin A. Reproduction 124: 173-180 (2002).

Lohnes D, Kastner P, Dierich A, Mark M, LeMeur M, Chambon P: Function of retinoic acid receptor gamma in the mouse. Cell 73:643-658 (1993).

Lohnes D, Mark M, Mendelsohn C, Dolle P, Dierich A, Gorry P, Gansmuller A, Chambon P: Function of the retinoic acid receptors (RARs) during development (I). Craniofacial and skeletal abnormalities in RAR double mutants. Development 120:27232748 (1994). 
Lopez-Fernandez LA, del Mazo J: The cytosolic aldehyde dehydrogenase gene (Aldh1) is developmentally expressed in Leydig cells. FEBS Lett 407:225229 (1997).

Lufkin T, Lohnes D, Mark M, Dierich A, Gorry P, Gaub MP, LeMeur M, Chambon P: High postnatal lethality and testis degeneration in retinoic acid receptor alpha mutant mice. Proc Natl Acad Sci USA 90:7225-7229 (1993).

Luo J, Pasceri P, Conlon RA, Rossant J, Giguere V: Mice lacking all isoforms of retinoic acid receptor beta develop normally and are susceptible to the teratogenic effects of retinoic acid. Mech Dev 53: 61-71 (1995).

Malkov M, Fisher Y, Don J: Developmental schedule of the postnatal rat testis determined by flow cytometry. Biol Reprod 59:84-92 (1998).

Mangelsdorf DJ, Evans RM: The RXR heterodimers and orphan receptors. Cell 83:841-850 (1995).

Mangelsdorf DJ, Umesono K, Evans RM: The Retinoid Receptors, in Sporn MB, Roberts AB, Goodman DS (eds): The Retinoid, Biology, Chemistry, and Medicine, 2nd ed, pp 319-349 (Raven Press, New York 1994).

Mason KE: Differences in testes injury and repair after vitamin A deficiency, Vitamin E deficiency and inanition. Am J Anat 52:153-239 (1933)

Matsumiya K, Meistrich ML, Shetty G, Dohmae K, Tohda A, Okuyama A, Nishimune Y: Stimulation of spermatogonial differentiation in juvenile spermatogonial depletion (jsd) mutant mice by gonadotropin-releasing hormone antagonist treatment. Endocrinology 140:4912-4915 (1999).

McCarthy PT, Cerecedo LR: Vitamin A deficiency in the mouse. J Nutr 46:361-376 (1952).

Mehta PP, Bertram JS, Loewenstein WR: Growth inhibition of transformed cells correlates with their junctional communication with normal cells. Cell 44:187-196 (1986)

Meng X, Lindahl M, Hyvonen ME, Parvinen M, de Rooij DG, Hess MW, Raatikainen-Ahokas A Sainio K, Rauvala H, Lakso M, Pichel JG, Westphal H, Saarma M, Sariola H: Regulation of cell fate decision of undifferentiated spermatogonia by GDNF. Science 287:1489-1493 (2000).

Miller ME, Cross FR: Cyclin specificity: how many wheels do you need on a unicycle? J Cell Sci 114:1811-1820 (2001).

Mitranond V, Sobhon P, Tosukhowong P, Chindaduangrat W: Cytological changes in the testes of vitamin-A-deficient rats. I. Quantitation of germinal cells in the seminiferous tubules. Acta Anat 103:159-168 (1979).

Mizoguchi S, Kim KH: Expression of cdc25 phosphatases in the germ cells of the rat testis. Biol Reprod 56:1474-1481 (1997).

Molotkov A, Deltour L, Foglio MH, Cuenca AE, Duester G: Distinct retinoid metabolic functions for alcohol dehydrogenase genes $A d h 1$ and $A d h 4$ in protection against vitamin A toxicity or deficiency revealed in double null mutant mice. J Biol Chem 277:13804-13811 (2002).

Monaco HL: The transthyretin-retinol-binding protein complex. Biochim Biophys Acta 1482:65-72 (2000).

Morales A, Cavicchia JC: Spermatogenesis and bloodtestis barrier in rats after long-term Vitamin A deprivation. Tissue Cell 34:349-355 (2002).

Morales C, Griswold MD: Retinol-induced stage synchronization in seminiferous tubules of the rat. Endocrinology 121:432-434 (1987).

Morales CR, Griswold MD: Variations in the level of transferrin and SGP-2 mRNAs in Sertoli cells of vitamin A-deficient rats. Cell Tissue Res 263:125130 (1991).

Nagpal S, Chandraratna RA: Vitamin A and regulation of gene expression. Curr Opin Clin Nutr Metab Care 1:341-346 (1998).
Nakayama K, Ishida N, Shirane M, Inomata A, Inoue T, Shishido N, Horii I, Loh DY: Mice lacking p27(Kip1) display increased body size, multiple organ hyperplasia, retinal dysplasia, and pituitary tumors. Cell 85:707-720 (1996).

Napoli JL, McCormick AM: Tissue dependence of retinoic acid metabolism in vivo. Biochim Biophys Acta 666:165-175 (1981).

Niederreither K, Subbarayan V, Dolle P, Chambon P: Embryonic retinoic acid synthesis is essential for early mouse post-implantation development. Nat Genet 21:444-448 (1999).

Niederreither K, Abu-Abed S, Schuhbaur B, Petkovich M, Chambon P, Dolle P: Genetic evidence that oxidative derivatives of retinoic acid are not involved in retinoid signaling during mouse development. Nat Genet 31:84-88 (2002).

Noy N: Physical-chemical properties and action of retinoids, in Nau H, Blaner WS (eds): Retinoids: The Biochemical and Molecular Basis of Vitamin A and Retinoid Action, pp 3-29 (Springer-Verlag, Berlin 1999).

Nurse PM: Nobel Lecture. Cyclin dependent kinases and cell cycle control. Biosci Rep 22:487-499 (2002).

Oakberg EF: A description of spermiogenesis in the mouse and its use in an analysis of the cycle of the seminiferous epithelium and germ cell renewal. Am J Anat 99:391-414 (1956).

Ohta H, Tohda A, Nishimune Y: Proliferation and differentiation of spermatogonial stem cells in the $W /$ $W v$ mutant mouse testis. Biol Reprod 30:30 (2003).

Ong DE, Newcomer ME, Chytil F: Cellular retinoidbinding proteins, in Sporn MB, Roberts AB, Goodman DS (eds): The Retinoid, Biology, Chemistry, and Medicine, 2nd ed, pp 283-317 (Raven Press, New York 1994).

Orth JM: Proliferation of Sertoli cells in fetal and postnatal rats: a quantitative autoradiographic study. Anat Rec 203:485-492 (1982).

Packer AI, Wolgemuth DJ: Genetic and molecular approaches to understanding the role of retinoids in mammalian spermatogenesis, in Nau H, Blaner WS (eds): Retinoids: The Biochemical and Molecular Basis of Vitamin A and Retinoid Action, pp 347-368 (Springer-Verlag, Berlin 1999).

Pestell RG, Albanese C, Reutens AT, Segall JE, Lee RJ, Arnold A: The cyclins and cyclin-dependent kinase inhibitors in hormonal regulation of proliferation and differentiation. Endocr Rev 20:501-534 (1999).

Piedrafita FJ, Pfahl M: Nuclear retinoid receptors and mechanisms of action, in Nau H, Blaner WS (eds): Retinoids: The Biochemical and Molecular Basis of Vitamin A and Retinoid Action, pp 153-184 (Springer-Verlag, Berlin 1999).

Pitts JD, Hamilton AE, Kam E, Burk RR, Murphy JP: Retinoic acid inhibits junctional communication between animal cells. Carcinogenesis 7:1003-1010 (1986).

Quadro L, Blaner WS, Salchow DJ, Vogel S, Piantedosi R, Gouras P, Freeman S, Cosma MP, Colantuoni $\mathrm{V}$, Gottesman ME: Impaired retinal function and vitamin A availability in mice lacking retinol-binding protein. EMBO J 18:4633-4644 (1999).

Rajan N, Kidd GL, Talmage DA, Blaner WS, Suhara A, Goodman DS: Cellular retinoic acid-binding protein messenger RNA: levels in rat tissues and localization in rat testis. J Lipid Res 32:1195-1204 (1991).

Rajguru SU, Kang YH, Ahluwalia BS: Localization of retinol (vitamin A) in rat testes. J Nutr 112:18811891 (1982).

Reed SI: Cell cycling? Check your brakes. Nat Cell Biol 4:E199-201 (2002).
Roberts JM: Evolving ideas about cyclins. Cell 98:129_ 132 (1999).

Rogers MB: Life-and-death decisions influenced by retinoids. Curr Top Dev Biol 35:1-46 (1997).

Ross AC: Retinoid production and catabolism: role of diet in regulating retinol esterification and retinoic acid oxidation. J Nutr 133:291S-296S (2003).

Russell LD, Ettlin RA, SinhaHikim AP, Clegg ED: Histological and histopathological evaluation of the testis (Cache River Press, Clearwater 1990).

Sakai Y, Meno C, Fujii H, Nishino J, Shiratori H, Saijoh Y, Rossant J, Hamada $\mathrm{H}$ : The retinoic acidinactivating enzyme CYP26 is essential for establishing an uneven distribution of retinoic acid along the anterio-posterior axis within the mouse embryo. Genes Dev 15:213-225 (2001).

Satoh H, Zhong Y, Isomura H, Saitoh M, Enomoto K, Sawada N, Mori M: Localization of 7H6 tight junction-associated antigen along the cell border of vascular endothelial cells correlates with paracellular barrier function against ions, large molecules, and cancer cells. Exp Cell Res 222:269-274 (1996).

Schrans-Stassen BH, Saunders PT, Cooke HJ, de Rooij DG: Nature of the spermatogenic arrest in Dazl-/mice. Biol Reprod 65:771-776 (2001).

Sherr CJ, Roberts JM: CDK inhibitors: positive and negative regulators of G1-phase progression. Genes Dev 13:1501-1512 (1999).

Shetty J, Marathe GK, Dighe RR: Specific immunoneutralization of FSH leads to apoptotic cell death of the pachytene spermatocytes and spermatogonial cells in the rat. Endocrinology 137:2179-2182 (1996).

Smith SM, Levy NS, Hayes CE: Impaired immunity in vitamin A-deficient mice. J Nutr 117:857-865 (1987).

Sobhon P, Mitranond V, Tosukhowong P, Chindaduangrat W: Cytological changes in the testes of vitamin-A-deficient rats. II. Ultrastructural study of the seminiferous tubules. Acta Anat 103:169_ 183 (1979).

Sueoka N, Lee HY, Walsh GL, Hong WK, Kurie JM: Posttranslational mechanisms contribute to the suppression of specific cyclin:CDK complexes by all-trans retinoic acid in human bronchial epithelial cells. Cancer Res 59:3838-3844 (1999).

Suzuki R, Shintani T, Sakuta H, Kato A, Ohkawara T, Osumi N, Noda M: Identification of RALDH-3, a novel retinaldehyde dehydrogenase, expressed in the ventral region of the retina. Mech Dev 98:37$50(2000)$.

Tahayato A, Dolle P, Petkovich M: Cyp26C1 encodes a novel retinoic acid-metabolizing enzyme expressed in the hindbrain, inner ear, first branchial arch and tooth buds during murine development. Gene Expr Patterns 3:449-454 (2003).

Taimi M, Helvig C, Wisniewski J, Ramshaw H, White J, Amad M, Korczak B, Petkovich M: A novel human cytochrome P450, CYP26C1 involved in metabolism of 9-cis and all-trans, isomers of retinoic acid. J Biol Chem 7:77-85 (2003).

Takase S, Ong DE, Chytil F: Transfer of retinoic acid from its complex with cellular retinoic acid-binding protein to the nucleus. Arch Biochem Biophys 247:328-334 (1986).

Thang SH, Kobayashi M, Matsuoka I: Regulation of glial cell line-derived neurotrophic factor responsiveness in developing rat sympathetic neurons by retinoic acid and bone morphogenetic protein-2. J Neurosci 20:2917-2925 (2000).

Thompson JN, Howell JM, Pitt GA: Vitamin A and reproduction in rats. Proc R Soc Lond B Biol Sci 159:510-535 (1964)

Tohda A, Matsumiya K, Tadokoro Y, Yomogida K, Miyagawa Y, Dohmae K, Okuyama A, Nishimune $\mathrm{Y}$ : Testosterone suppresses spermatogenesis in juvenile spermatogonial depletion (jsd) mice. Biol Reprod 65:532-537 (2001). 
Tsutsui T, Hesabi B, Moons DS, Pandolfi PP, Hansel KS, Koff A, Kiyokawa H: Targeted disruption of CDK4 delays cell cycle entry with enhanced p27(Kip1) activity. Mol Cell Biol 19:7011-7019 (1999).

Van Pelt AM, de Rooij DG: The origin of the synchronization of the seminiferous epithelium in vitamin A-deficient rats after vitamin A replacement. Biol Reprod 42:677-682 (1990a).

van Pelt AM, de Rooij DG: Synchronization of the seminiferous epithelium after vitamin A replacement in vitamin A-deficient mice. Biol Reprod 43:363-367 (1990b).

van Pelt AM, de Rooij DG: Retinoic acid is able to reinitiate spermatogenesis in vitamin A-deficien rats and high replicate doses support the full development of spermatogenic cells. Endocrinology 128:697-704 (1991).

van Pelt AM, van den Brink CE, de Rooij DG, van der Saag PT: Changes in retinoic acid receptor messenger ribonucleic acid levels in the vitamin A-deficient rat testis after administration of retinoids. Endocrinology 131:344-350 (1992).

Vogel S, Gamble MV, Blaner WS: Biosynthesis, absorption, metabolism and transport of retinoids, in Nau $\mathrm{H}$ Blaner WS (eds): Retinoids: The Biochemical and Molecular Basis of Vitamin A and Retinoid Action, pp 31-95 (Springer-Verlag, Berlin 1999).

Walder L, Lutzelschwab R: Effects of 12-O-tetradecanoylphorbol-13-acetate (TPA), retinoic acid and diazepam on intercellular communication in a monolayer of rat liver epithelial cells. Exp Cell Res 152:66-76 (1984).
Walker WH: Molecular mechanisms controlling Sertoli cell proliferation and differentiation. Endocrinology 144:3719-3721 (2003).

Weil M, Jacobson MD, Raff MC: Are caspases involved in the death of cells with a transcriptionally inactive nucleus? Sperm and chicken erythrocytes. J Cell Sci 111:2707-2715 (1998).

Weiler R, He S, Vaney DI: Retinoic acid modulates gap junctional permeability between horizontal cells of the mammalian retina. Eur J Neurosci 11:33463350 (1999).

White JA, Beckett-Jones B, Guo YD, Dilworth FJ, Bonasoro J, Jones G, Petkovich M: cDNA cloning of human retinoic acid-metabolizing enzyme (hP450RAI) identifies a novel family of cytochromes P450. J Biol Chem 272:18538-18541 (1997).

Wing TY, Christensen AK: Morphometric studies on rat seminiferous tubules. Am J Anat 165:13-25 (1982).

Wolbach SB, Howe PR: Tissue changes following deprivation of fat-soluble A vitamin. J Exp Med 42:753-777 (1925).

Wolgemuth DJ, Watrin F: List of cloned mouse genes with unique expression patterns during spermatogenesis. Mamm Genome 1:283-288 (1991).

Wolgemuth DJ, Rhee K, Wu S, Ravnik SE: Genetic control of mitosis, meiosis and cellular differentiation during mammalian spermatogenesis. Reprod Fertil Dev 7:669-683 (1995).
Wolgemuth DJ, Laurion E, Lele KM: Regulation of the mitotic and meiotic cell cycles in the male germ line. Recent Prog Horm Res 57:75-101 (2002).

Yang ZW, Wreford NG, de Kretser DM: A quantitative study of spermatogenesis in the developing rat testis. Biol Reprod 43:629-635 (1990).

Zgombic-Knight M, Ang HL, Foglio MH, Duester G: Cloning of the mouse class IV alcohol dehydrogenase (retinol dehydrogenase) cDNA and tissue-specific expression patterns of the murine $\mathrm{ADH}$ gene family. J Biol Chem 270:10868-10877 (1995).

Zhai Y, Sperkova Z, Napoli JL: Cellular expression of retinal dehydrogenase types 1 and 2: effects of vitamin A status on testis mRNA. J Cell Physiol 186:220-232 (2001).

Zhang Q, Wang X, Wolgemuth DJ: Developmentally regulated expression of cyclin D3 and its potential in vivo interacting proteins during murine gametogenesis. Endocrinology 140:2790-2800 (1999).

Zheng WL, Bucco RA, Schmitt MC, Wardlaw SA, Ong DE: Localization of cellular retinoic acid-binding protein (CRABP) II and CRABP in developing rat testis. Endocrinology 137:5028-5035 (1996).

Zhong Y, Enomoto K, Tobioka H, Konishi Y, Satoh M, Mori M: Sequential decrease in tight junctions as revealed by $7 \mathrm{H} 6$ tight junction-associated protein during rat hepatocarcinogenesis. Jpn J Cancer Res 85:351-356 (1994).

Zhou Q, Stetler-Stevenson M, Steeg PS: Inhibition of cyclin D expression in human breast carcinoma cells by retinoids in vitro. Oncogene 15:107-115 (1997). 